\title{
The Scarab and Scaraboid Seals in the Egyptian Collection of the Museum of Cultural History, University of Oslo
}

\author{
Stephanie Müller
}

\begin{abstract}
The Museum of Cultural History in Oslo is home to a small but fine ancient Egyptian collection. For my Magister thesis at the University of Heidelberg, I had the pleasure of conducting research on the 98 scarabs and scaraboid seals in the collection. The study focused on the bottom motifs and the multifunctional purposes for their owners as well as the important insights they provide into common religious beliefs in ancient Egyptian society. This short overview of the research conducted in Oslo presents all twelve attested bottom motifs and introduces the most remarkable objects in the collection. Covering a time span from the Twelfth Dynasty until the Late Period and most probably the Roman Period, the scarabs and scaraboid seals in the museum bear testimony to 2000 years of cultural history, providing fascinating details about the religious beliefs of the common people as well as demonstrating the importance of these objects in everyday life.
\end{abstract}

Ancient Egyptian scarabs have always evoked wonder and fascination, as hundreds of thousands of these little objects were produced for a period of around 2000 years. ${ }^{1}$ Unfortunately, despite being one of the most abundant types of artefact remaining from ancient Egypt, they remain largely neglected in studies relating to ancient Egyptian culture.

The ancient Egyptians associated the rolling of dung-balls by scarabaeus sacer with the movement of the sun across the sky, and gave the action a religious significance by connecting it to the concept of afterlife resurrection. The beetle rolling a ball of dung was compared to the 'arising [of] the sun from the horizon in the eternal circle of solar rebirth'. ${ }^{2}$ In order to provide the desired magical impact to protect the owner, scarabs were worn as amulets, but were also used in administrative contexts as seals

\footnotetext{
${ }^{1}$ I am grateful to Dr Marina Prusac-Lindhagen, Associate Professor and Keeper of the Egyptian and Antiquity Collection, and Senior Adviser Anette Sxttem, who generously granted permission to undertake a detailed examination of all scarabs in the MCH for my Magister Artium thesis, The Scarabs and Scaraboid Seals in the Collection of the Museum of Cultural History in Oslo, University of Heidelberg, 2013. I would also like to thank the anonymous peer reviewers, and last, but not least, Kristin Bornholdt Collins for improving the language. In the following I present a general overview of the results of my research. Reference numbers beginning with $\mathrm{C}$ relate to the inventory numbers of the items in the collection.
}

2 Wilkinson 2008, 11. 
to impress a design or name of ownership, and they were also certainly considered to be a form of jewellery.

In total, there are 98 scarabs and scaraboid seals dating from the Twelfth Dynasty until the Late Period and most probably the Roman Period in the collection of the Museum of Cultural History, University of Oslo (MCH).

The variety of bottom motifs reflects the variety of meanings and functions that scarabs had. The scarab and scaraboid seals in the MCH can be categorised into twelve bottom motif classes. For nine out of 98 objects the bottom motif could not be identified with certainty, or at all, due to the rather poor quality of the engraving. During the research it appeared that one scarab, C41094, which is the only scarab completely inscribed with a text on its bottom, is most likely a forgery; the same is true of scarab C47249, for which there is an almost identical forgery. ${ }^{3}$ Furthermore, there is one scarab fragment (C47416) made of black glass, which based on its decoration of the back and plain bottom probably originated in the Roman Period, and is therefore the youngest object in the scarab collection.

Scarabs were regularly produced from the pre-Twelfth Dynasty until the Late Period. ${ }^{4}$ The massive production of scarabs in ancient Egyptian times, as well as the poor quality that is a general feature, support the assumption that scarabs were used as protecting amulets by the lower classes of the population. By thematically analysing the bottom motifs of scarabs and scaraboid seals in the $\mathrm{MCH}$ collection, this article aims to provide valuable insights into the everyday religious beliefs and practices of ancient Egyptian society.

\section{Overview of the twelve represented bottom motif classes}

\section{Geometric patterns}

Seven objects could be assigned to the class 'geometric pattern', which includes bottom designs with scroll borders, concentric circles, spirals and cross patterns. ${ }^{5}$ The meaning of these patterns is not yet clear. Professor of the Archaeology of Eretz Israel, Amnon Ben-Tor assumed that the geometric patterns had not just an ornamental purpose, but they might have possessed a magical significance as well. ${ }^{6}$ Assistant archaeologists in the Harvard Expedition to Giza, Noel F. Reisner and George A. Wheeler suggested that the 'scroll border' motif, which can be seen on the bottom of scarab C41220 (Fig.1), was used as a personal and individual motif in order to serve as a private seal for the owner. ${ }^{7}$ Wheeler's assumption is supported by the fact that a massive number of scarabs with geometric patterns have been found, but there are only a few exact parallels among them. The distinct meaning of the concentric circles

\footnotetext{
${ }^{3}$ See Schulman 1970, 193-196.

${ }^{4}$ Ward 1978, 8-9; Ward \& Dever 1994, 89-93. See Ben-Tor 1993 for an overview of the functions of scarabs.

${ }^{5}$ C41220, C41230, C47184, C47190, C47192, C47209, C47235.

${ }^{6}$ Ben-Tor 1993, 31.

${ }^{7}$ Reisner \& Wheeler 1930, 52-54.
} 


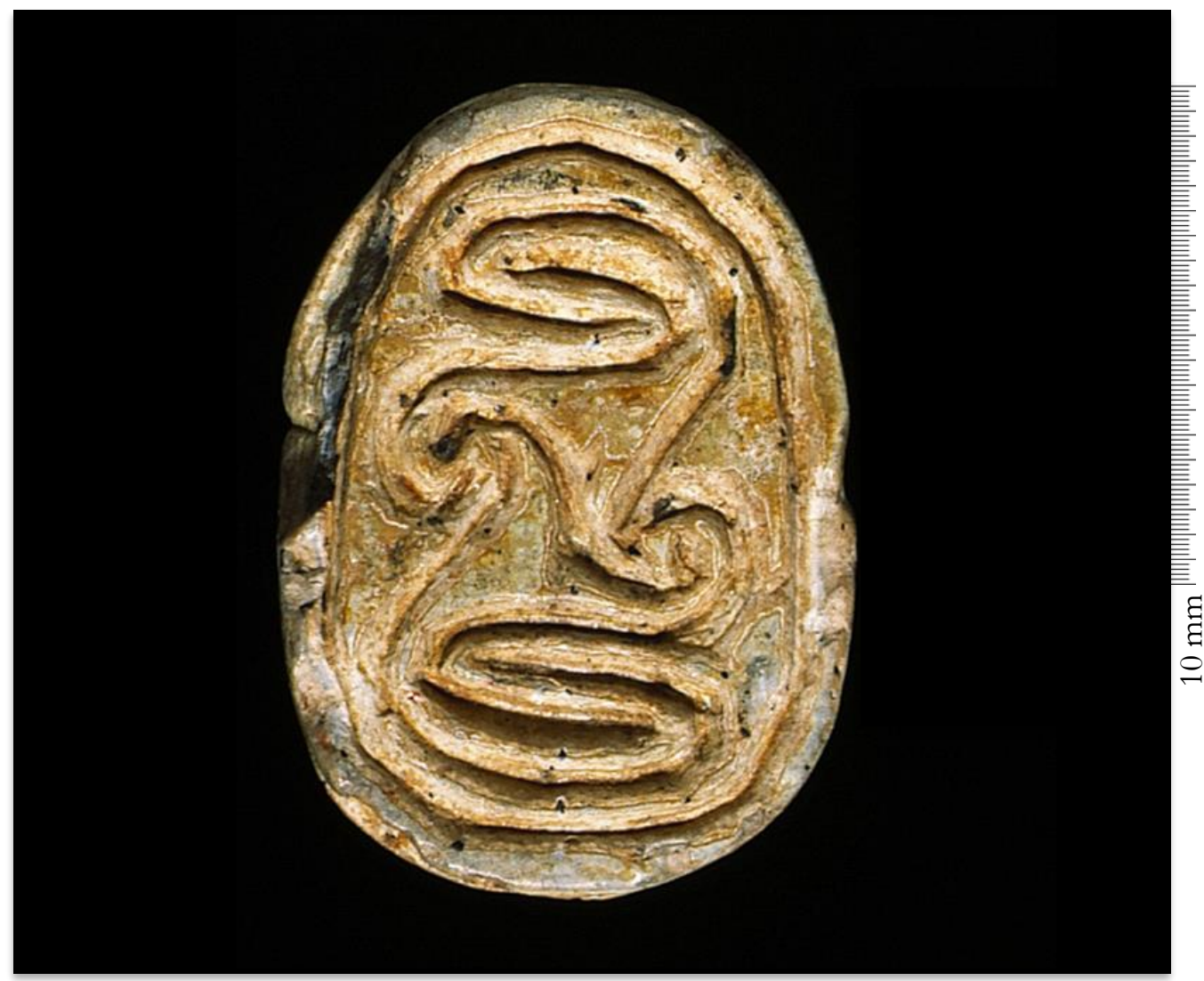

Fig. 1 Bottom of scarab. Oslo, MCH inv. no. C41220.

Photograph: (C) Stephanie Müller.

as inscribed on the bottom of scarab C41230 and C47235 (Fig. 2) is unknown. According to Egyptologists Erik Hornung and Elisabeth Staehelin the concentric circle resembled a sun-disc. ${ }^{8}$ Turkish explorer Nimet Özgüc understood the concentric circle with a centred dot as a symbol for an eye, which he attested on Anatolian monuments of the second millennium BC. ${ }^{9}$ Professor of the Old Testament and biblical world Otmar Keel presumed that both interpretations could be valid, as the sun-disc was a symbol identified by the ancient Egyptians as the eye of Horus, or the eye of the sky. ${ }^{10}$ The bottom of scarab C47184 (Fig. 3) is decorated with three unlinked Z-spirals next to each other. The origin, meaning and usage of this motif on scarabs is controversial. While Egyptologists William A. Ward and Harry R. Hall assumed an Egyptian origin, Near Eastern Archaeologist and Art Historian Helen Kantor supported a Minoan provenience. ${ }^{11}$ Keel and Hildi Keel-Leu supported the

\footnotetext{
${ }^{8}$ Hornung \& Staehelin 1976, 166.

9 Özgüç 1993, 510-514.

${ }^{10}$ Keel 1995, 182.

11 Hall 1929, 13-14; Kantor 1947, 21-32; Ward 1978, 54.
} 


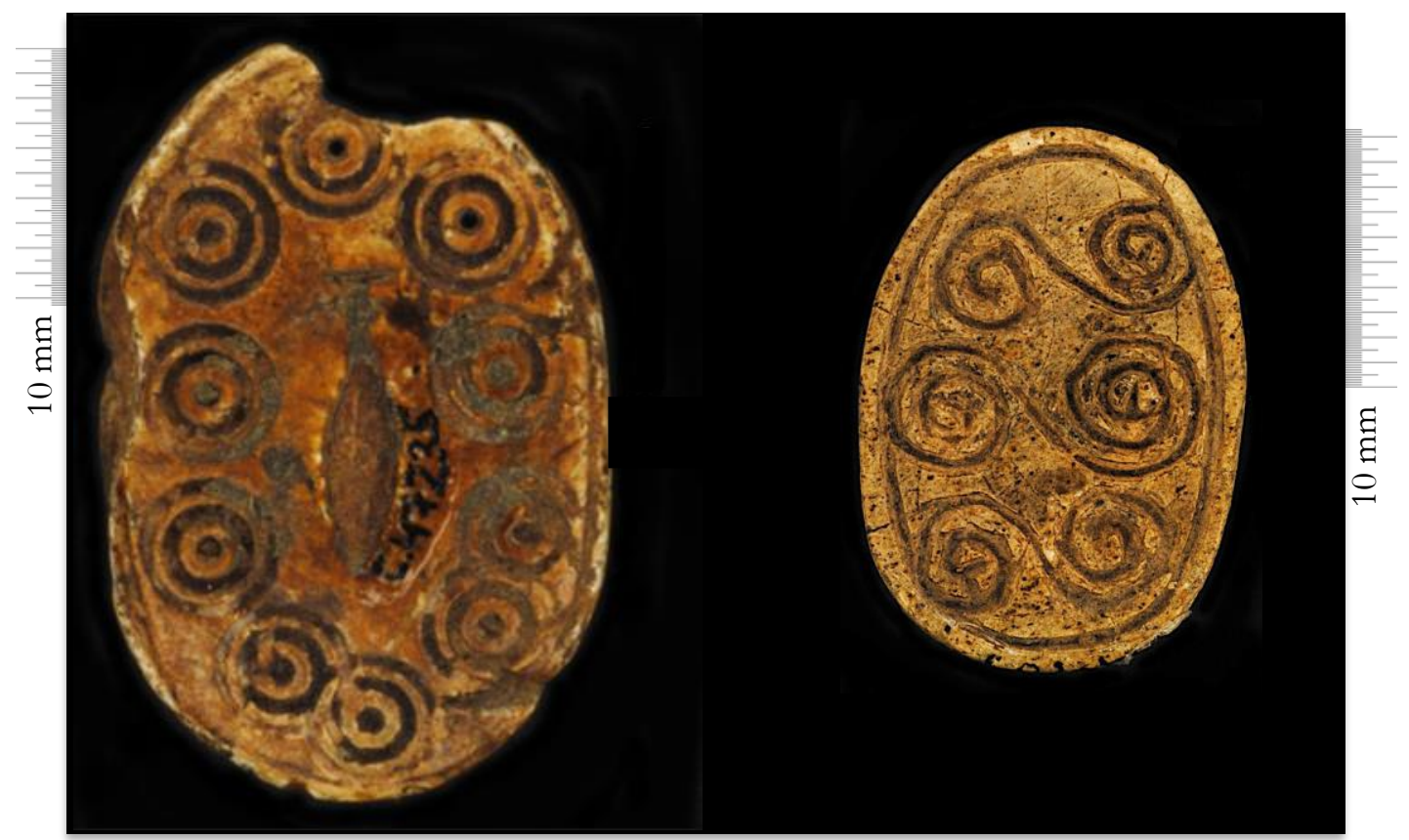

Fig. 2 (left) Bottom of scarab. Oslo, MCH inv. no. C47235.

Fig. 3 (right) Bottom of scarab. Oslo, MCH inv. no. C47184. Photographs: (C) Stephanie Müller.

non-Egyptian origin of the motif and assumed an origin in south-east Europe. ${ }^{12}$ Professor of Egyptology Wolfgang Helck supported the proposed Minoan origin, as the spiral motif was in all probability a Minoan seal impression inherited by the Egyptians without giving the motif a functional meaning. ${ }^{13} \mathrm{Ward}$, on the other hand, suggested that the abstract spiral motif originated from simple Egyptian plant motifs, particularly from curled plant stems, which according to him were part of the standard art tradition of the Old Kingdom. ${ }^{14}$ According to Egyptologist Alice Grenfell, the single and double spiral symbolised the word 'life', as they substituted an 9 -sign on two scarabs he studied. ${ }^{15}$ Hornung and Staehelin also assumed that the spiral pattern symbolised the renewal of life. ${ }^{16}$ Professor of Egyptology Hanns Stock assumed a more practical meaning for the spiral motif since, according to his research, scarabs with an ornamental pattern were mostly found associated with places of daily life and administrative sites, and he therefore proposed a use as seal. ${ }^{17}$ Egyptologist Magdalena Stoof was convinced that scarabs with spiral motifs could have had more than one

\footnotetext{
${ }^{12}$ Keel 1995, 164; Keel-Leu 1989, 5-6.

${ }^{13}$ Helck 1984, 1158-1159.

${ }^{14}$ Ward 1971, 111-113 and figs. 22-24.

${ }^{15}$ Grenfell 1916, 23, 31 nos. 111-114.

${ }^{16}$ Hornung \& Staehelin 1976, 166.

${ }_{17}$ Stock 1942, 18.
} 


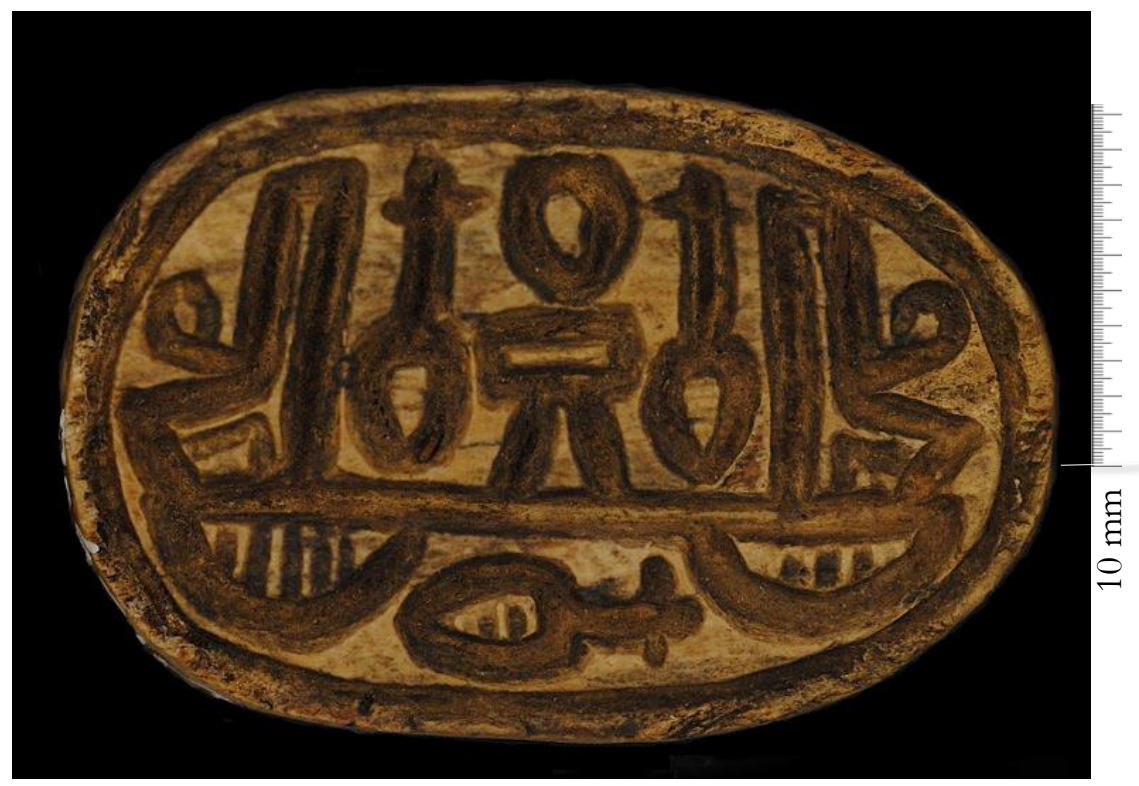

Fig. 4 Bottom of scarab. Oslo, MCH, inv. no. C42508.

Photograph: C Stephanie Müller.

meaning, i.e. a religious as well as an administrative one. ${ }^{18}$ She thought that scarabs with simple spiral patterns were most likely used as seals, as the pattern could be easily formed into unique images, while scarabs found in tombs are likely to have had an amuletic function. ${ }^{19}$

\section{Symbols}

A second class of 'symbols' for bottom motifs could be attested in the collection of the MCH and includes seven scarabs and one scaraboid (Fig. 4), which are decorated with signs of the Egyptian language..$^{20}$ The latter had a strong symbolic meaning and were therefore used as protective signs functioning as amulets for the deceased as well as for the living. ${ }^{21}$ The characteristic of these hieroglyphic signs is that they did not compose words, but were rather used for their magical significance. ${ }^{22}$ The most common of these signs were those representing the words 'protection', 'life', 'duration' and 'luck/perfection'. ${ }^{23}$ During the Hyksos Period in particular, symbols were popular as bottom motifs on scarabs. ${ }^{24}$ From the Middle Kingdom until the end of the New

\footnotetext{
18 Stoof $1983,35$.

19 Stoof 1983, 35, 44. For scarabs with names and titles of officials framed by spirals see Martin 1971.

${ }^{20}$ C42508, C47171, C47179, C47201, C47204, C47205, C47217, C47239.

${ }^{21}$ Hornung \& Staehelin 1976, 168.

22 Ben-Tor 1993, 31; Stock 1942, 16. 21; Petrie 1925, 18.

${ }^{23}$ Hornung \& Staehelin 1976, 168. An overview of the most frequent symbols on scarabs is given by Stock 1942, 18-19; Hornung \& Staehelin, 1976, 168-169.

${ }^{24}$ Hornung \& Staehelin 1976, 168.
} 


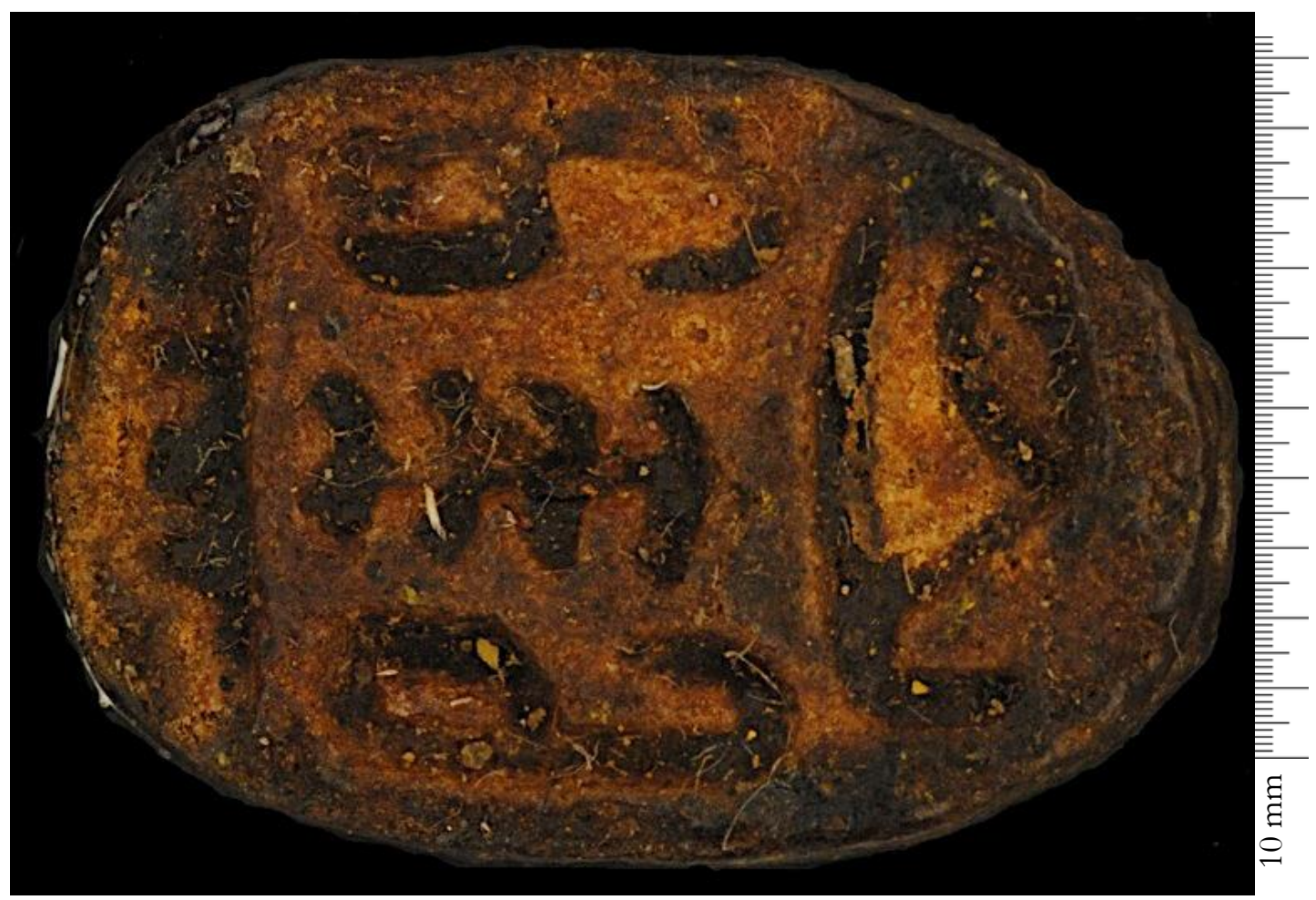

Fig. 5 Bottom of scarab. Oslo, MCH inv. no. C47213.

Photograph: (C) Stephanie Müller.

Kingdom the production of scarabs inscribed with symbols decreased until they were only used as cryptographic signs. ${ }^{25}$

\section{The anra formula}

A special sign sequence, 'the anra formula', could be attested on two scarabs in the collection and forms its own motif class (Fig. 5). ${ }^{26}$ The formula is defined and identified by a sequence of hieroglyphs appearing on the bottom of a scarab that always includes at least two of the letters of the sequence $a-n-r-a$ in a line. ${ }^{27}$ This motif was researched in detail by archaeologist Fiona Virginia Richards in $2001 .^{28}$ The explanation of the meaning of the anra formula has resulted in many different interpretations. Weill, who named the scarab anra or nera for the first time proposed the reading of $D u$ - ne - $r a$ as 'the gift of Re', indicating an epithet of Ra and not a name..$^{29}$ Later on, he suggested the reading Erdara and the transcription $\mathrm{R} a-n-\mathrm{R} a$, which he took as a mistaken writing of 'Ra gave', a frequent type of a theophoric name

${ }^{25}$ Hornung \& Staehelin 1976, 168.

${ }^{26}$ C47213, C47246.

${ }^{27}$ Hornung \& Staehelin 1976, 51; Niccacci 1980, 24; Richards 2001, 11.

${ }_{28}^{2}$ Richards 2001.

29 Petrie 1919, 46. 
in the Middle Kingdom. ${ }^{30}$ In 1930, pioneering Egyptologist Professor Flinders Petrie proposed that the anra sequence was perhaps copied incorrectly from an Egyptian original, which may have read as $s A-\mathrm{R} a$, 'protection by $\mathrm{Ra} .{ }^{31}$ Other researchers such as Egyptologist Margaret A. Murray and biblical scholar Alviero Niccacci interpreted the sequence as 'name of Ra', which were used as amulets for magical protection. ${ }^{32}$ Hornung and Staehelin suggested a connection with the name of $\mathrm{Ra}$, but only for those objects with the full written anra sequence, or an association with the word $r n$, 'name', or with the word $n r$, 'scare'. ${ }^{33}$ Furthermore, both believed that the formula could also be one of the 'abracadabra' magical words that existed in later Egyptian magical texts. ${ }^{34}$ Richards is convinced that the anra sequence displayed the name of the Ugarit god El, which she tried to prove by using the Egyptian group writing or syllabic orthography to spell the Semitic letter 'l' by the combination of the signs $n+$ $r r^{35}$ Furthermore, Richards assumed a strong parallel between the gods $\mathrm{El}$ and $\mathrm{R} a$, which according to her gives the formula a meaning in Egypt. ${ }^{36}$ Finally, a definite explanation for the meaning of the anra formula cannot be given. According to Hornung and Staehelin, this group of scarabs was an innovation of the Hyksos Period. ${ }^{37}$ Richards is convinced that the concept of the anra scarab came from Egypt and that these scarabs were produced for the Palestinian market in Egypt in the Fifteenth Dynasty, and that they might have been manufactured in Palestine later on as well. ${ }^{38}$

\section{The king, royal motifs and other humans}

Several scarabs ${ }^{39}$ in the MCH collection could be assigned to the motif class 'the king, royal motifs and other humans'. In the Hyksos Period the depiction of gods, animals and humans increased enormously. ${ }^{40}$ In the New Kingdom, the portrayal of the king and other royal motifs became the most popular decoration on scarabs. ${ }^{41}$ The king appeared in several scenes in different roles based on the royal dogma. The earliest

\footnotetext{
30 Petrie 1925, 17.

31 Petrie 1930, 3.

32 Murray 1949, 96; Niccacci 1980, 30.

${ }^{33}$ Hornung \& Staehelin 1976, 51

34 Hornung \& Staehelin 1976, 51. not apply to the SIP'. See Richards 2001, 151.

36 Richards 2001, 158-159.

37 Hornung \& Staehelin 1976, 51.

38 Richards 2001, 117. For further information see Richards 2001, 16-21.

${ }^{39}$ C41229, C47170, C47172, C47188, C47189, C47191, C47194, C47230.

${ }^{40}$ Hornung \& Staehelin 1976, 188.

${ }^{41}$ Hornung \& Staehelin 1976, 188; Wiese 1990, 135.
}

35 Richards 2001, 150-152. Richards used Schenkel (1986) and Hoch (1994, 407; 487; 496-497) to prove the development of the letter ' $\mathrm{l}$ ' from the sign combination $\mathrm{n}+\mathrm{r}$. Furthermore, Richards gave literary examples for the development of the letter '1', which is dated to the New Kingdom period. See Richards 2001, 151. According to Osing, the $\mathrm{n}+\mathrm{r}$ combination dates back to the Old Kingdom. See Osing 1980, 945-949. Richards concluded that 'there is no reason why it should 


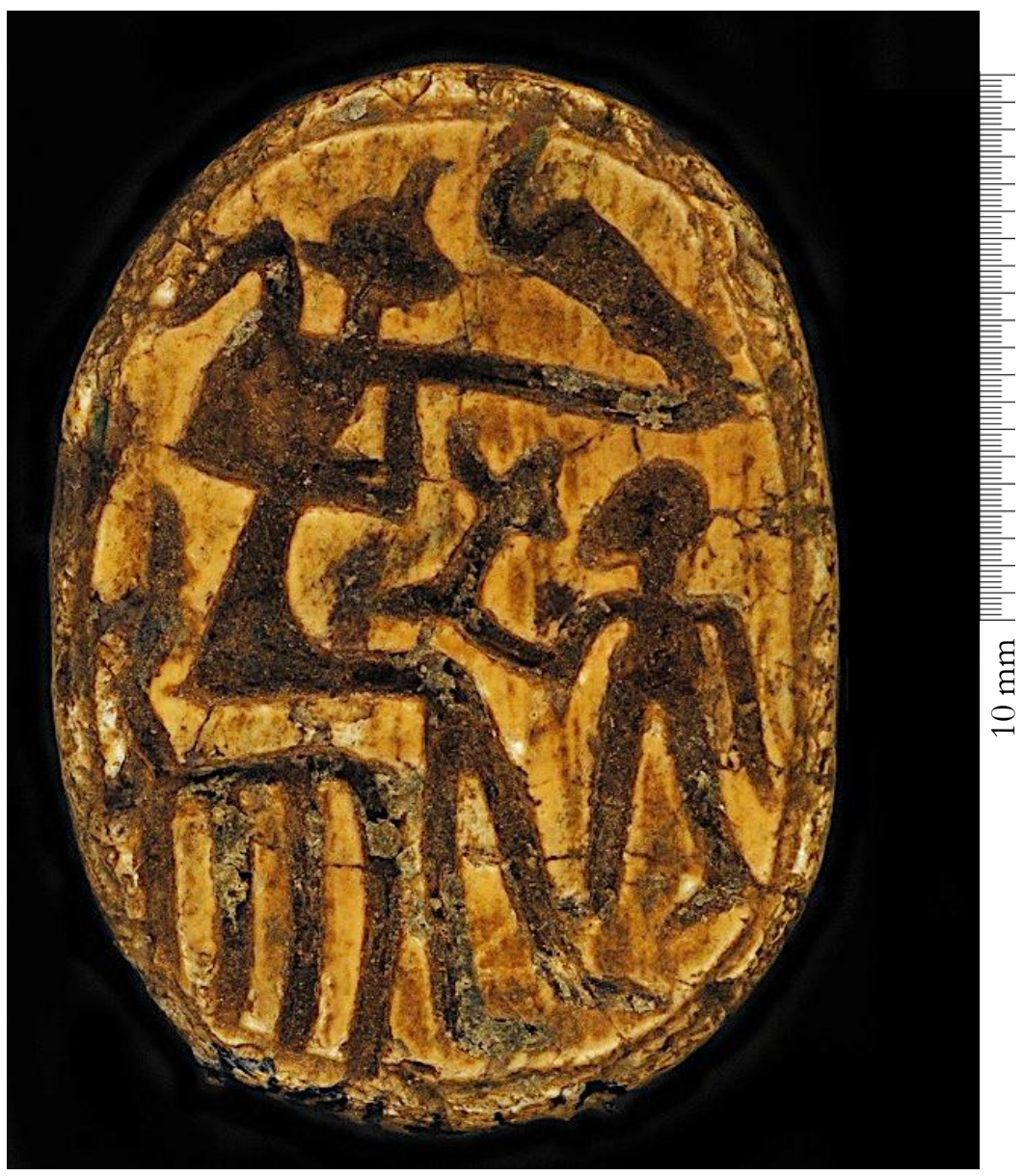

Fig. 6 Bottom of scarab. Oslo, MCH inv. no. C47188. Photograph: (C) Stephanie Müller.

royal motifs showed the king in a standing or enthroned position as displayed on the bottoms of the scarabs C47170, C47172, C47188 (Fig. 6), and C47230. ${ }^{42}$ Professor of Egyptology André B. Wiese proposed that the king in this scene represented the ruling king in the role of Horus as an expression of royal ideology, but at the same time also serves as an expression of state ideology. ${ }^{43}$ The king was the guarantor and preserver of the Maat, the world order, and according to Wiese, Hornung and Staehelin, his depiction as an emperor in a chariot displayed this royal duty and refers to a triumph scene of the pharaoh, which was used as a symbol of kingship itself as displayed on the bottom of C47191 (Fig. 7). ${ }^{44}$ Cooney and Wiese proposed that these royal images might have served propaganda purposes as well, as they reflected the legitimisation of

\footnotetext{
${ }^{42}$ The first scarabs with these decorations are attested from the reign of Ahmose. See Hornung \& Staehelin 1976, 188.

${ }^{43}$ Wiese 1990, 138-139, 141-142.

${ }^{44}$ Hornung \& Staehelin 1976, 189; Wiese 1990, 81, 137-138.
} 


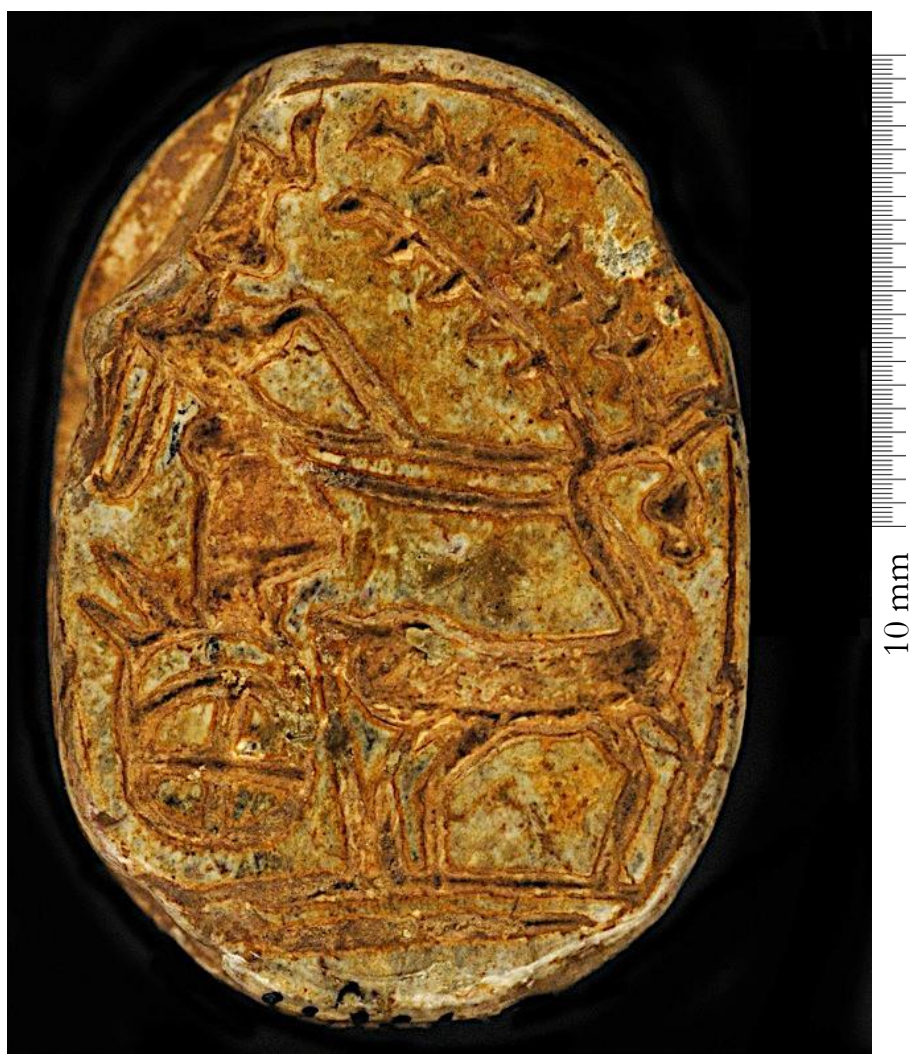

Fig. 6 Bottom of scarab. Oslo, MCH inv. no.

C47188. Photograph: (C) Stephanie Müller.

the king and the religious and political propaganda of the state..$^{45}$ This function would give the scarab production and distribution a political meaning. The depictions of the kings on the bottoms of the scarabs in the $\mathrm{MCH}$ collection are anonymous, as according to Hornung and Staehelin it was not the individual king that was important, but rather the victorious and apotropaic power of the Egyptian kingship itself. ${ }^{46}$ The motif of a sitting human figure on a throne (C47170, C47172) and the image of an anonymous, enthroned king with an anonymous worshipper (C47188, C47230) (Fig. 6) are especially common motifs in this class. Furthermore, a common motif is a scene displaying a bowman confronting two animals as inscribed on the bottom of scarab C47189 (Fig. 8), which are most probably two lions. According to Professor Richard H. Wilkinson, the bow was a symbol of monarchical power in ancient Egypt and was used in gestures expressing dominance. ${ }^{47}$ The lion was associated with the attributes 'strength' and 'bravery', analogous to the character of the pharaoh. ${ }^{48}$ It is conceivable

\footnotetext{
45 Cooney \& Tyrell 2005, 5; Wiese 1990, 140.

46 Hornung \& Staehelin 1976, 188.

47 Wilkinson 1994, 200.

48 Köhler 1980, 1080.
} 


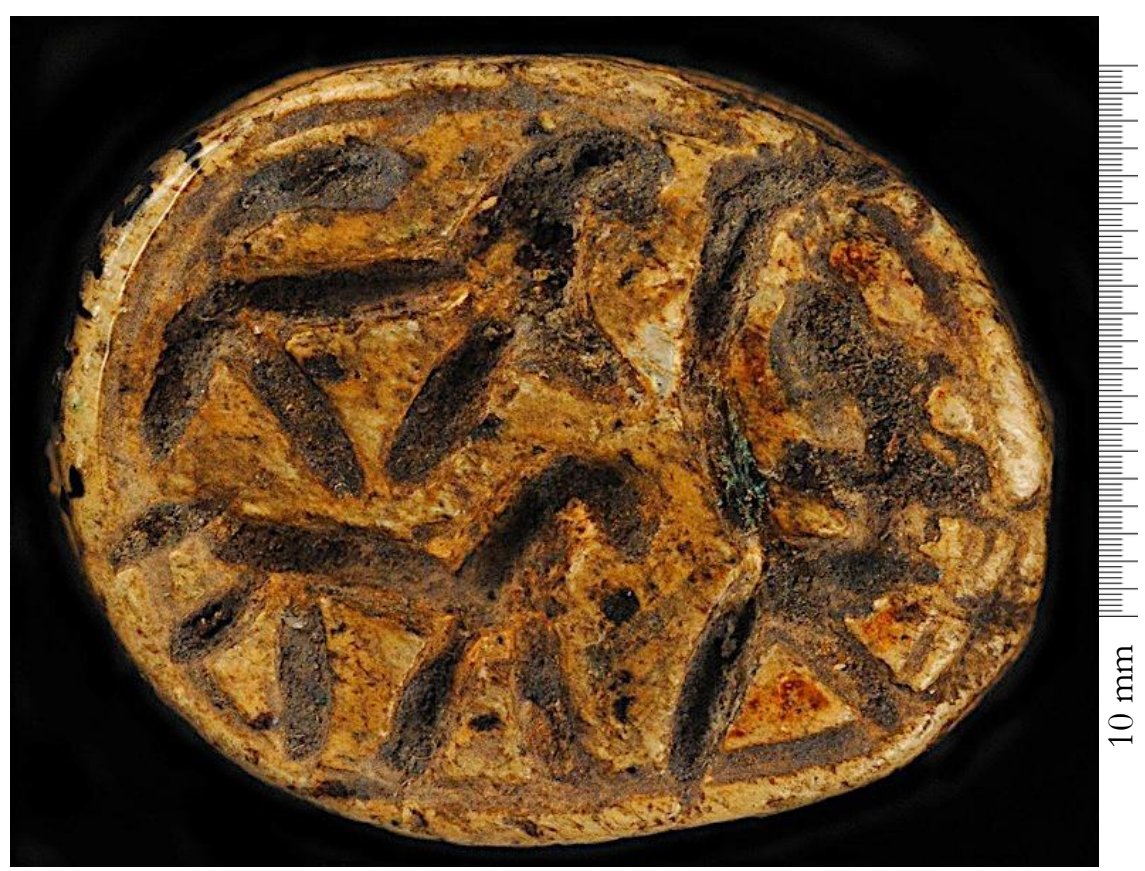

Fig. 8 Bottom of scarab. Oslo, MCH, inv. no. C47189.

Photograph: (C) Stephanie Müller.

that the intention was to transfer the royal strength, power and bravery from a lion's hunt scene to the owner of the scarab.

\section{King's names}

In the Egyptian collection of the $\mathrm{MCH}$ in Oslo twelve out of 98 scarabs were engraved with the throne name of Thutmose III (18th Dynasty) which is one of the most common bottom motifs of the scarabs in the collection. ${ }^{49}$ The inscription of the king's name on the bottom of the scarabs aimed to intensify the magical power of the scarab amulet. ${ }^{50}$ The pharaoh was believed to have an intrinsic power, which was transferred to the owner of the scarab. This belief may explain why the names and figures of the king were by far the most common motif on scarabs. ${ }^{51}$ An enhancement of the protective power of the pharaoh's name was reached by doubling the name, which was particularly popular under Thutmose III, whose throne name $\mathrm{Mn}$ - $\mathrm{H} p r$-Ra is inscribed on the bottom of scarab C47244 (Fig. 9). ${ }^{52}$

Since the New Kingdom period, king names on scarabs also had a cryptographic meaning like writing of the god's name Amun, which according to Hornung and

${ }^{49}$ C41 221, C41 228, C41 249, C47 164, C47 168, C47 175, C47 196, C47 197, C47 198, C47 214, C47 241, C47244.

${ }^{50}$ Hornung \& Staehelin 1976, 41.

51 Conney 2005, 9; Hornung \& Staehelin 1976, 41

${ }^{52}$ Hornung \& Staehelin 1976, 42. 


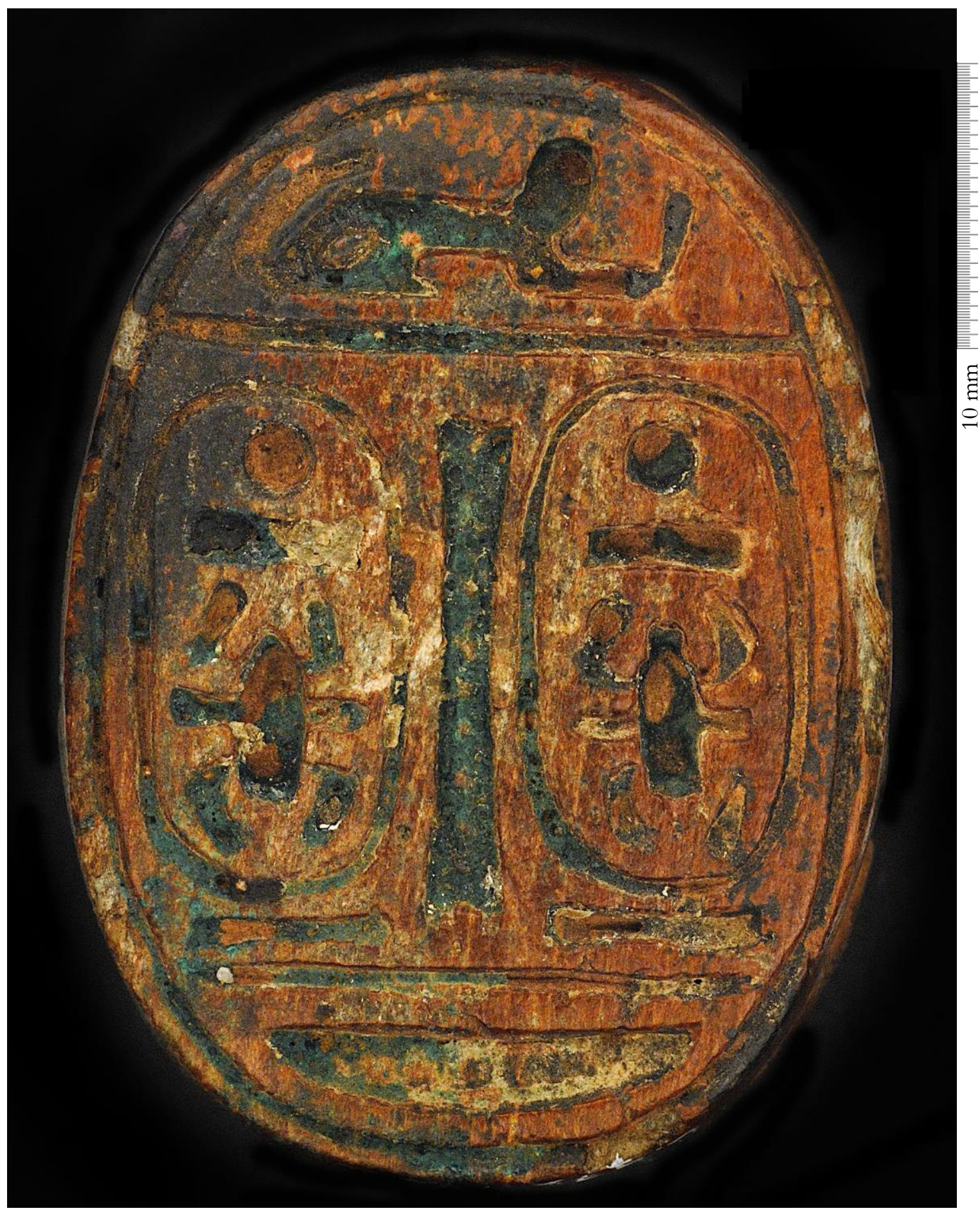

Fig. 9 Bottom of scarab. Oslo, MCH inv. no. C47244. Photograph: (C) Stephanie Müller. 
Staehelin strongly influenced the utilisation of the names of kings on scarabs. ${ }^{53}$ According to Egyptologist Bertrand Jaeger, the cryptographic writing of the name Amun was a jeu de l'esprit ${ }^{54}$ corresponding to the meaning of the god's name, 'the one who is hidden'. ${ }^{55}$ As in cryptographic writing, the $m n$-sign stands for the letter ' $m$ ', $h p r$ stands for the letter ' $n$ ', and Ra for the letter ' $j$ ', so the three signs form the name Jmn. ${ }^{56}$ The name $\mathrm{Mn}-\mathrm{H} p r-\mathrm{R} a$ is the most prominent example for the ambiguity of the names of kings.

There is only one scarab in the collection inscribed with a different throne name. The throne name of Sety II, $W s r-h p r w-R a$, is inscribed on the bottom of scarab C47176 (Fig. 10), whose size (38 mm length $\mathrm{x} 28 \mathrm{~mm}$ width $\mathrm{x} 18 \mathrm{~mm}$ height) is distinctly bigger than the majority ${ }^{57}$ of the scarabs in the $\mathrm{MCH} .{ }^{58}$ The motif of two feathered cartouches, the writing of the throne name in a cartouche, as well as the size might indicate an administrative usage of scarab C47176 as a royal seal. ${ }^{59}$

\section{Gods and mythical figures}

The depiction of divine and mythical figures was one of the most frequent bottom motifs on scarabs in general. In the collection of the $\mathrm{MCH}$ there are thirteen scarabs belonging to the motif class 'gods and mythical figures' ${ }^{60}$ In order to intensify the impact of the scarab, often more than one god was engraved. ${ }^{61}$ According to Ben-Tor, the scarabs engraved with divine beings were produced for the world of the living as only very few scarabs with images of gods were connected to the funerary cult. ${ }^{62}$ Among the represented gods is one depiction of the winged $B a^{c} a l-S e t h$ on the bottom of scarab C47202 (Fig. 11), and one depiction of the god Reshef standing on a gazelle or another horned animal with two lions confronting the god on the bottom of scarab

\footnotetext{
53 Hornung \& Staehelin 1976, 43.

54 Jaeger 1982, 94.

55 Jaeger 1982, 94.

${ }^{56}$ Following the derivation of a cryptographic used signs list provided by Jaeger 1982, 294.

57 The majority of the scarabs in the MCH have a length between 10-20 mm.

58 In publications about scarabs, size was not systematically taken into consideration as an indicator for deciding about the function of the scarab (with the exception of the heart and commemorative scarabs). Further research needs to be undertaken to investigate whether the size of the object can be used as an indicator for its use as a seal.

59 According to Martin, the pair of feathers attached atop the cartouche is a sign of the divine character of the king, and was only used in contexts that referred to the divine trait of the reigning king. See Martin 1990, 178-179. Furthermore, the writing of the throne name and epithets of Sety II in two cartouches are an indication for the production in his lifetime following Hornung \& Staehelin, who proposed that cartouches were more frequently used in the lifetime of a king. See Hornung \& Staehelin 1976, 61. Scarabs engraved with the throne name of Sety II and not dating to his lifetime are not known.

60 C47169, C47173, C47174, C47178, C47183, C47202, C47207, C47210, C47222, C47223, C47227, C47229, C47233.

61 Ben-Tor 1993, 35.

62 Ben-Tor 1993, 35.
} 


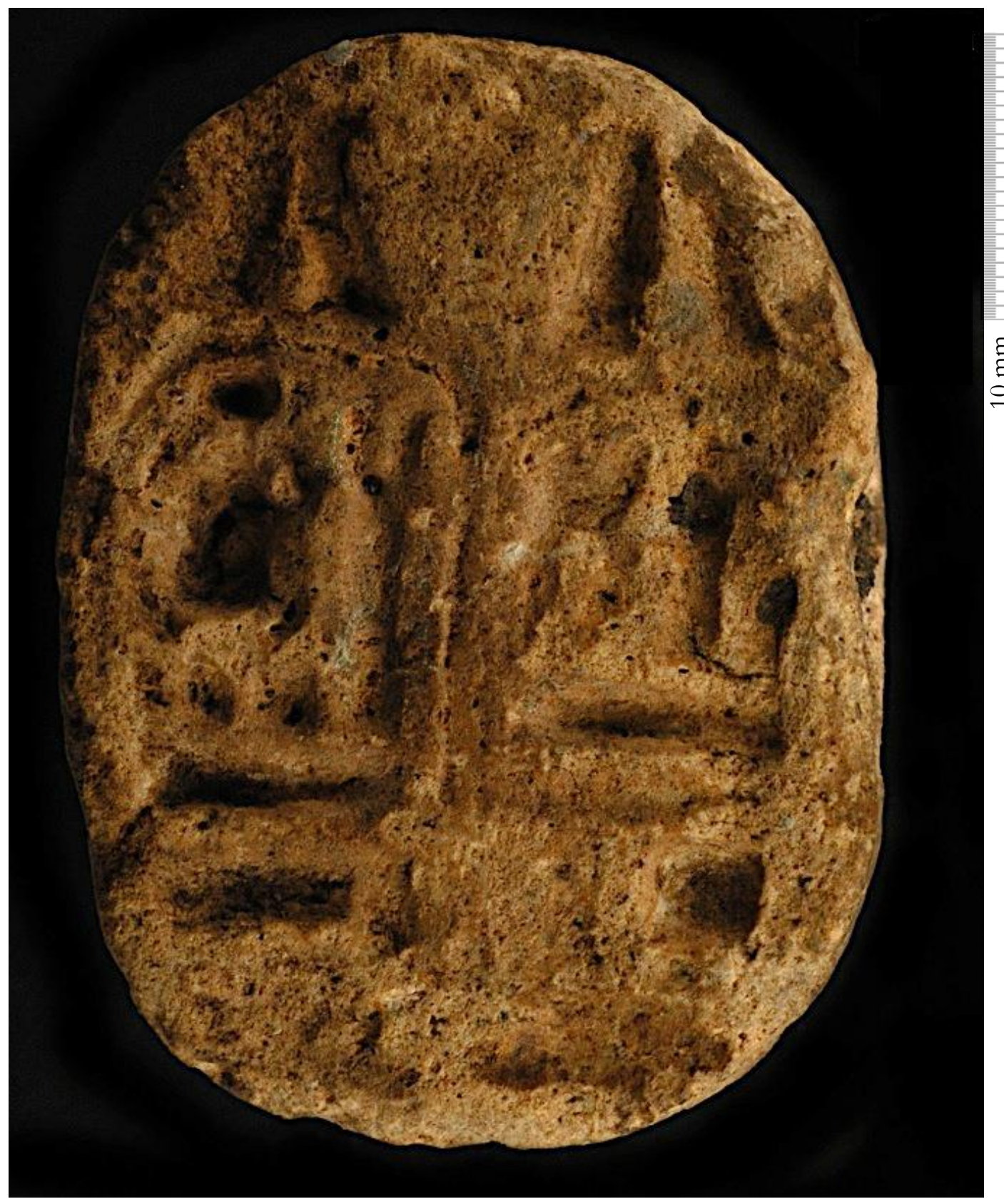

Fig. 10 Bottom of scarab. Oslo, MCH inv. no. C47176.

Photograph: (C) Stephanie Müller. 


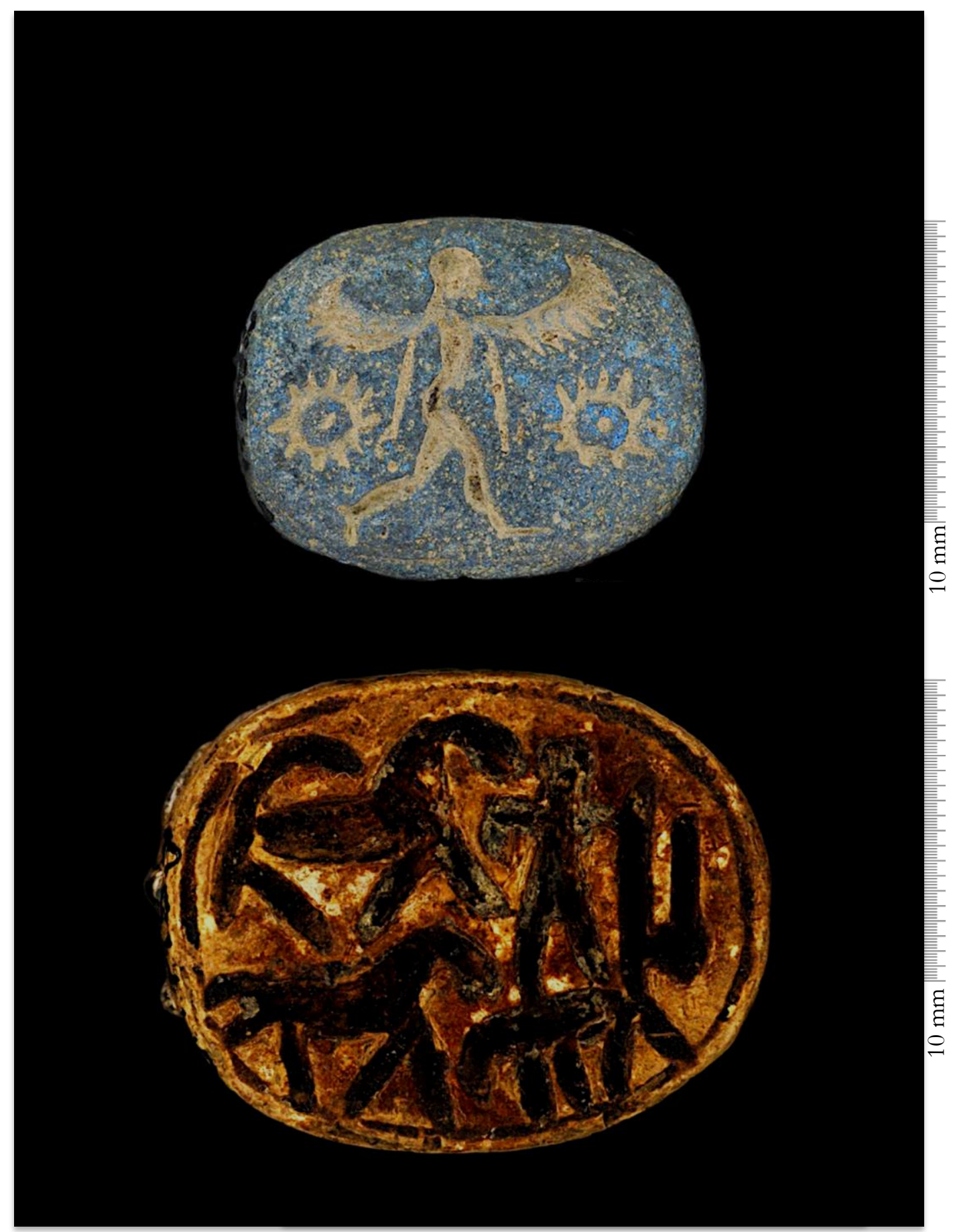

Fig. 11 (above) Bottom of scarab. Oslo, MCH inv. no. C47202. Fig. 12 (below) Bottom of scarab. Oslo, MCH inv. no. C47183. Photographs: (C) Stephanie Müller. 


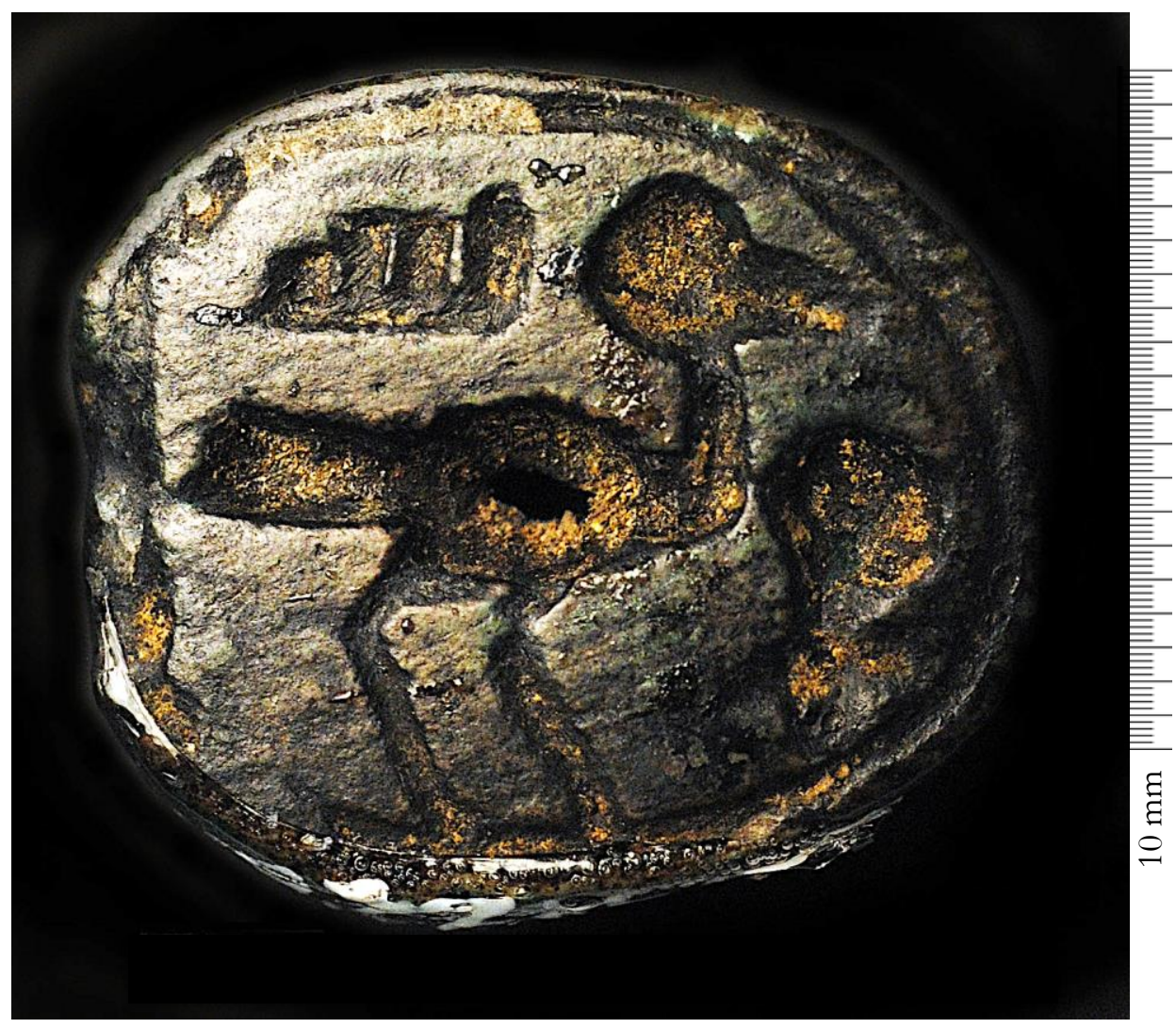

Fig. 13 Bottom of scarab. Oslo, MCH inv. no. C47226. Photograph: (C) Stephanie Müller.

C47183 (Fig. 12). Both are Canaanite gods, worshipped in the ancient Levant, but also attested in Egypt, Palestine and the Levant up to Byblos. ${ }^{63}$ Cornelius assumed that the depiction of Reshef on a horned animal with two lions reflects his lordship over wild animals as 'lord of the animals'. ${ }^{64}$

\section{Gods' names and cryptograms}

Additionally, the names of gods were frequently inscribed on scarabs, which proves the strong belief in the magical connotation of these names by the ancient Egyptians. ${ }^{65}$ Amun, the most important god in the New Kingdom, mostly appeared on scarabs by his name and not depicted as a figure (Fig. 13). This is probably connected to his hidden character. ${ }^{66}$ In the Egyptian collection of the $\mathrm{MCH}$, the only divine name

\footnotetext{
${ }^{63}$ Cornelius 1994, 122.

${ }^{64}$ Cornelius 1994, 124.

65 Hornung \& Staehelin 1976, 91.

${ }^{66}$ Keel 1995, 242; Hornung \& Staehelin 1976, 92.
} 
attested as an inscription on the scarabs is Amun. In total, eleven scarabs ${ }^{67}$ could be identified as being inscribed with the name of Amun by means of cryptographic writing used as an enigmatic reading of the god's name Amun. ${ }^{68}$ The name of Amun was expressed by forming the three letters $j-m-n$ by means of acrophony, hence creating new signs. ${ }^{69}$ Cooney emphasised the multi-layered function of scarabs inscribed with cryptograms. On the one hand, the cryptographic writing is a representation of personal piety to the god Amun/Amun-Ra. ${ }^{70}$ On the other hand, by displaying the throne name of a king, the object is also a piece with political meaning: '.... a social-political marker in addition to being an amulet that intimately tied its owner to the god Amun-Re. ${ }^{, 71}$ Therefore, a scarab with cryptic writing of the god's name Amun can be understood as an object binding together the owner, the king and the god.

\section{Animals}

Sixteen scarabs in the MCH collection can be assigned to the class 'animals', which underlines the popularity of animal motifs on scarabs. ${ }^{72}$ The most common animal depictions were lions (C41223, C47186, C47237), the cobra (C47218), birds (C47181, C47199) and monkeys (C47212, C47228) (Fig. 14). A lion is an animal of divine power associated with the goddess Sakhmet, and many other gods, who are mostly depicted with a human body and a lion's head. ${ }^{73}$ The characteristics of the lion were used to describe the king in literature, but the image of a lion was also used to represent the king. ${ }^{74}$ Furthermore, the lion represented a protecting, apotropaic power against hostile forces, and was associated with the sun. ${ }^{75}$ According to Keel, Hornung and Staehelin, the lion had a strong apotropaic meaning and was used as a symbol of force and danger. ${ }^{76}$ The image of a lion over a lying human body depicted on the bottom of scarab C41223 (Fig. 15) could therefore be a representation of the king trampling over an enemy.

The bird displayed on the bottom of scarab C47181 is most likely a falcon, which is the animal of the god Horus and referred to the king as it was described as a royal animal. ${ }^{77}$ Furthermore, a falcon was a symbol of regeneration and overcoming

${ }^{67}$ C41222, C47165, C47185, C47193, C47200, C47208, C47226, C47240, C47242, C47245, C47248.

${ }^{68}$ Hornung \& Staehelin 1976, 173; Jaeger 1982, 94.

${ }^{69}$ Drioton 1957, 11-12; Drioton 1933, 10-11. For a list of examples of acrophony see Drioton 1940, 396-397. For a list of cryptograms see Drioton 1940, 409-427.

70 Cooney \& Tyrell 2005, 4.

${ }^{71}$ Cooney \& Tyrell 2005, 4.

${ }^{72}$ C41223, C41250, C47166, C47180, C47181, C47186, C47199, C47212, C47218, C47224, C47228, C47231, C47232, C47234, C47236, C47237.

${ }^{73}$ Hornung \& Staehelin 1976, 126. For a complete list of gods see de Wit 1980, 191-368.

${ }^{74}$ Köhler 1980, 1086.

${ }^{75}$ Köhler 1980, 1081.

${ }^{76}$ Keel 1995, 196; Hornung \& Staehelin 1976, 126.

${ }_{77}$ Hornung \& Staehelin 1976, 136; Houlihan \& Goodman 1986, 48. 


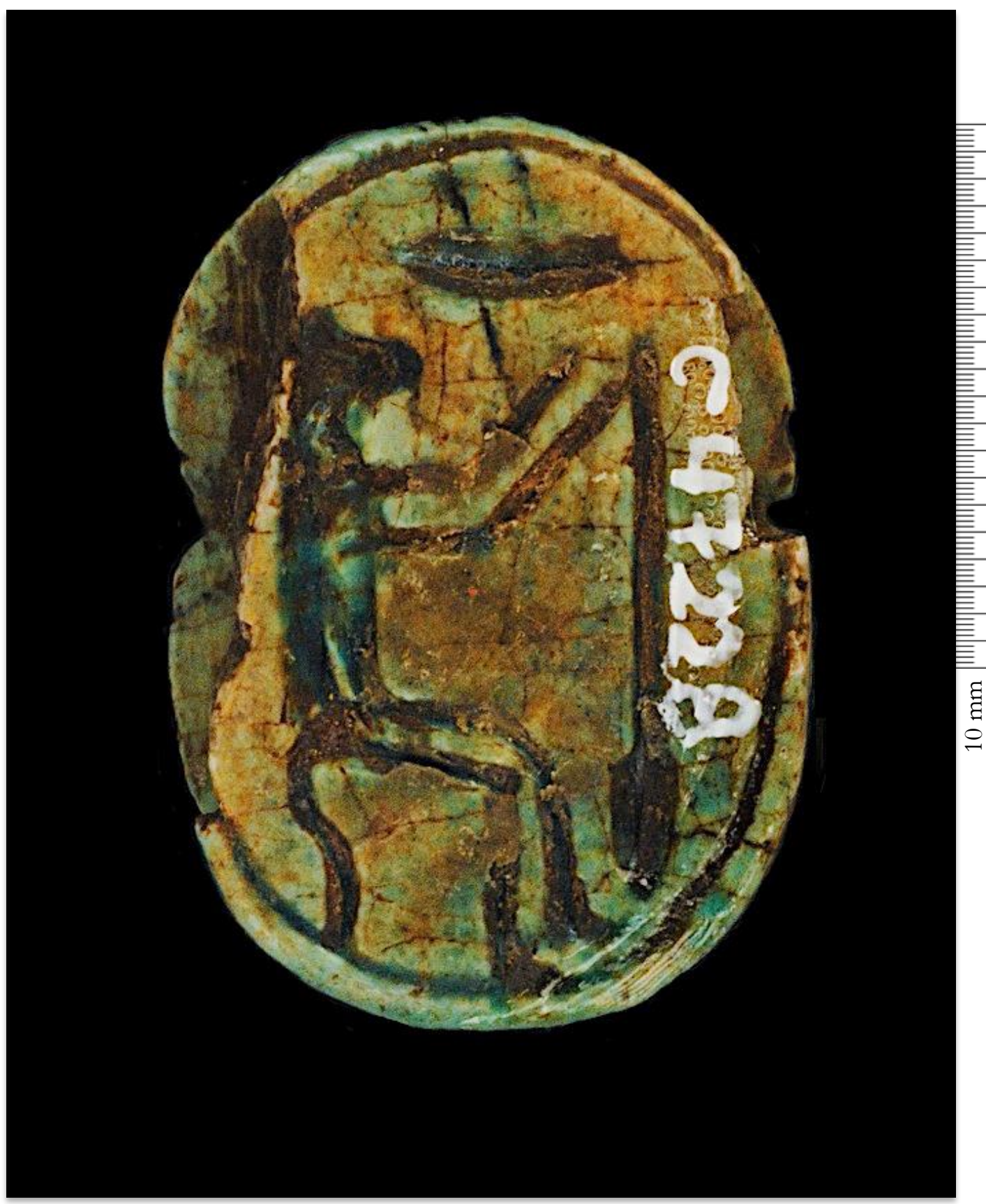

Fig. 14 Bottom of scarab. Oslo, MCH inv. no. C47228. Photograph: (C) Stephanie Müller. 


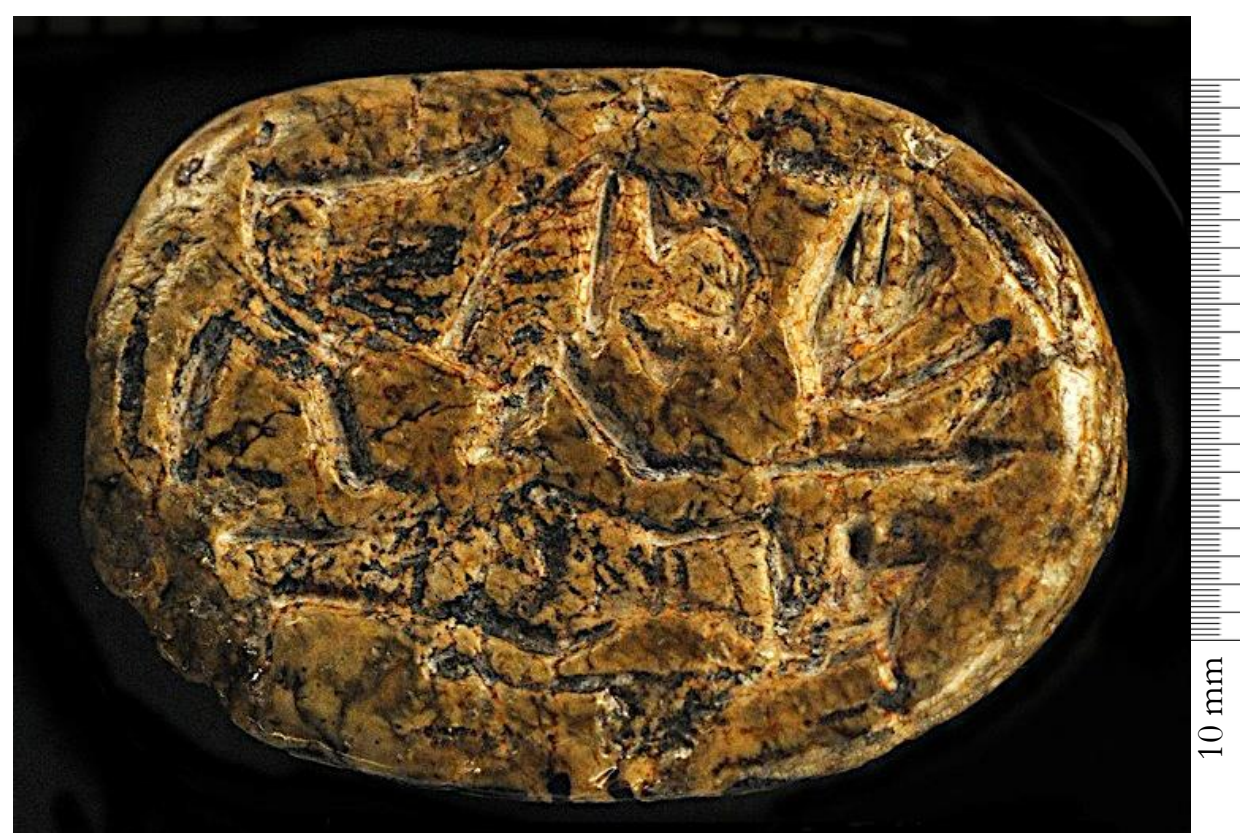

Fig. 15 Bottom of scarab. Oslo, MCH inv. no. C41223. Photograph: (C) Stephanie Müller.

death. ${ }^{78}$ The falcon motif is flanked by cobras. According to Hornung, Staehelin and Johnson, a cobra symbolises a protecting power, which uses its force against its enemies and is commonly associated with the royal and divine sphere. ${ }^{79}$ The depictions of monkeys, as on the bottom of the scarabs C47212 and C47228, were particularly common in the New Kingdom period, which could be read as the word nfrw, meaning 'the beautiful, the good', and might therefore express a wish for good or be a symbol of regeneration. ${ }^{80}$

\section{Private-name seals}

In addition to their religious function as amulets, scarabs were used as private-name seals in administrative contexts. ${ }^{81}$ According to G. T. Martin, Edwards Prof. of Egyptology 1988-93, private-name seals were used as a means of identification, and to authenticate and seal documents as well as to safeguard property. ${ }^{82}$ The bottoms of scarabs were therefore inscribed with the name and title of officials. The scarab C47182 (Fig. 16), which is inscribed with the sign sequence $m n-j-j$, was most probably a private-name seal. The name Mnjj is documented in Egyptologist Hermann Ranke's study about personal names as a male and female name in the Middle and New

\footnotetext{
${ }_{78}^{78}$ Hornung \& Staehelin 1976, 136.

${ }^{79}$ Hornung \& Staehelin 1976, 134; Johnson 1990, 5-6.

${ }^{80}$ Drioton 1955, 62; Erman \& Grapow 1955, 253; Hornung \& Staehelin 1976, 108.

${ }^{81}$ Detailed research on private-name seals was undertaken by Geoffrey Martin 1971.

${ }^{82}$ Martin 1971, xii.
} 


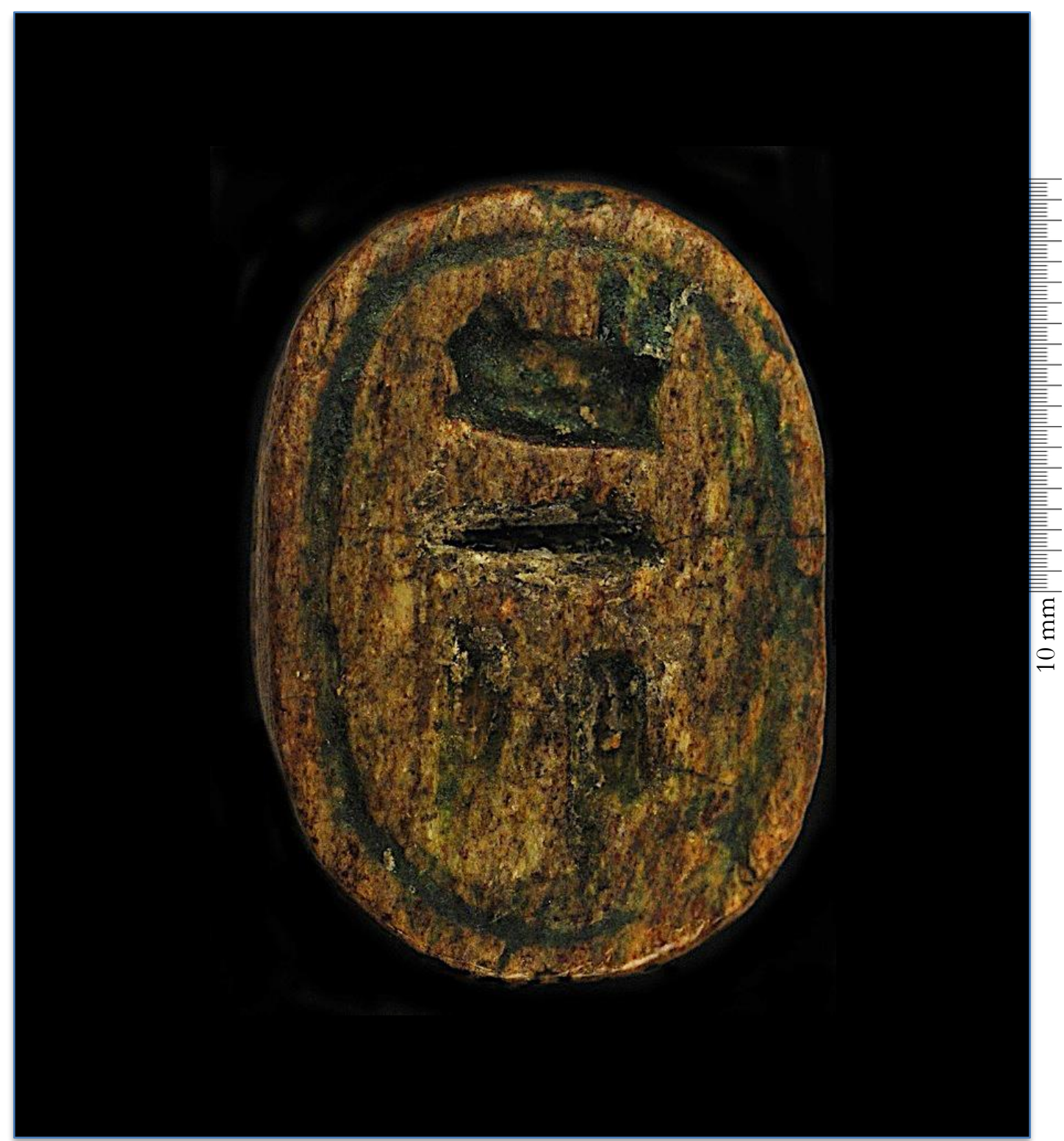

Fig. 16 Bottom of scarab. Oslo, MCH inv. no. C47182.

Photograph: (C) Stephanie Müller.

Kingdom periods. ${ }^{83}$ However, Mnij was also the name of the first Egyptian king Menes, and his name appeared in connection with Amun-Ra on three scarabs from Palestine dated from the New Kingdom to the Late Period. ${ }^{84}$ Jaeger gave further

83 Ranke 1935, 151 no.4.

${ }^{84}$ Keel 1995, 230; 1997, 546-547 no. 48 (Acco); Starkey \& Harding 1932, pl.57 no. 378 (Beth Pelet); Tufnell 1953, pl. 43 no. 18 (Lachish). 


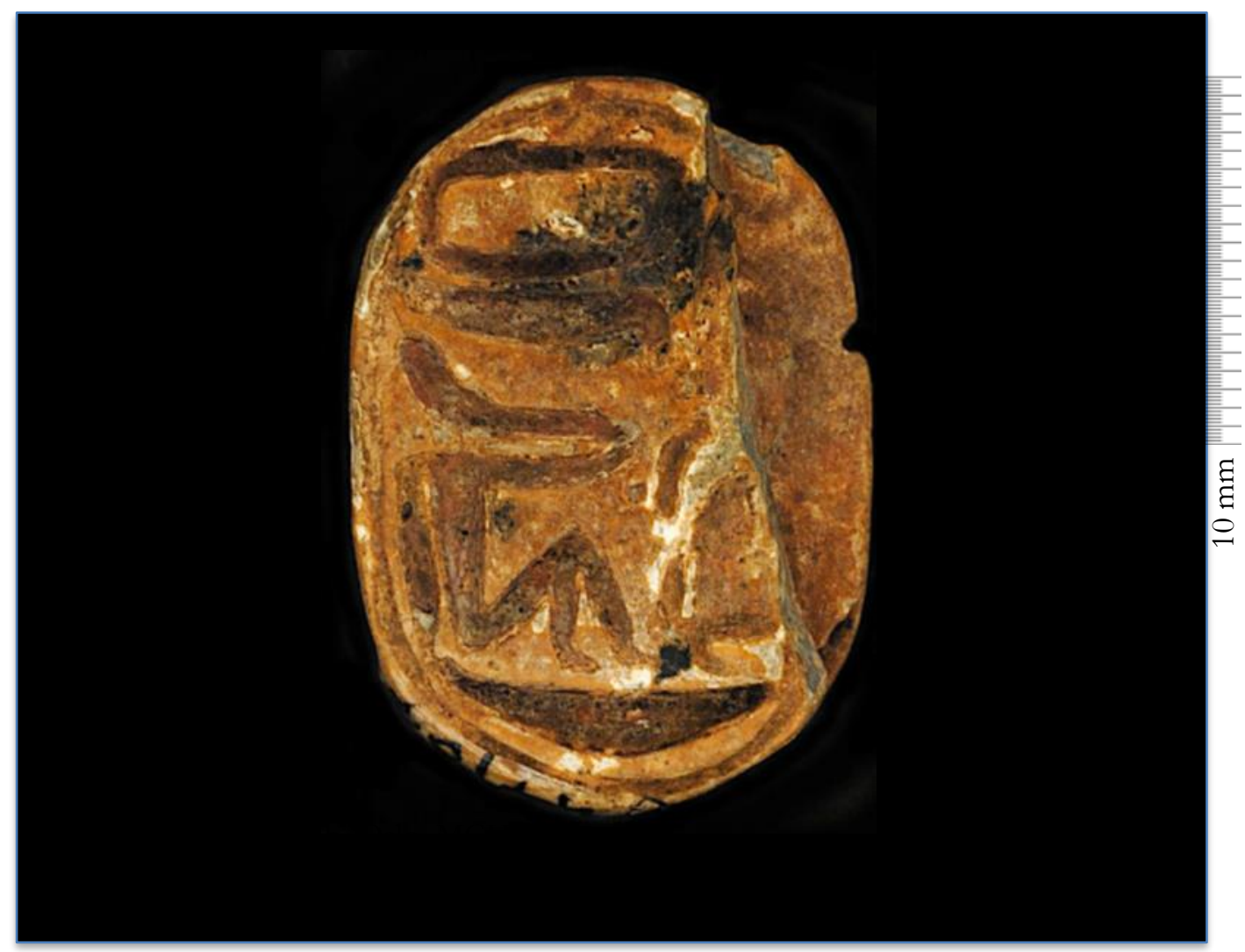

Fig. 17 Bottom of scarab. Oslo, MCH inv. no. C47187.

Photograph: (C) Stephanie Müller.

references to scarabs which are inscribed with the name $M n j j$ together with the throne name $M n-H p r-R a$ indicating a connection to the cryptograms of Amun. ${ }^{85}$ In conclusion, the scarab C47182 could have been used as a private-name seal by the owner Mnjj, and might as well have had a protective function as an amulet referring back to King Menes as well as referring to the god Amun through cryptographic writing.

\section{Formulae and wishes}

One scarab, C47187 (Fig. 17) can be assigned to the motif class 'formulae and wishes' as it is inscribed with a wishing formula called the 'child formula' by Hornung and Staehelin. ${ }^{86}$ The entire formula is read as $m n m=k$ h $m$ r mswt $=k:$ 'May your name endure, and may your posterity accomplish' ${ }^{87}$ According to Ben-Tor, this formula was

85 Jaeger 1982, 286 fn. 108.

${ }^{86}$ Hornung \& Staehelin 1976, 181. See also Drioton 1956.

87 'Translated by Ben-Tor as 'May your name endure and may you be blessed with children.' See Ben-Tor 1993, 34. See Drioton 1956, 35 no.2 with the display of the exact same sign sequence. 
a popular blessing for fertility, and secured the perpetuation of a person's memory through his descendants. ${ }^{88}$ Religious formulae, blessings and good luck formulae as well as wishes were often inscribed with cryptographic signs on scarabs, like on scarab C47187, in order to protect their owner and to facilitate the fulfilment of the wishes. ${ }^{89}$ Written formulae had such a strong magical power that the Egyptians believed bearing these formulae on scarab amulets ensured the fulfilment of the hopes and wishes. ${ }^{90}$ Scarab C47187 was certainly used as an amulet by the owner, who wished for children. Possibly the formula indicates a female owner.

\section{Naturalistic scarabs}

Another bottom motif class comprises all scarabs ${ }^{91}$ with naturalistic shaped bottoms in the $\mathrm{MCH}$ collection. They are exceptional as they were never inscribed, but the legs and the belly of the beetle were carved naturalistically. ${ }^{92}$ Frequently, these scarabs had a loop in the centre of the bottom, like scarab C47177 (Fig. 18), or were pierced laterally, like scarab C47243, so that the scarabs could be threaded on a string or appliquéd to the linen wrappings of a mummy. ${ }^{93}$ Generally, naturalistically-shaped scarabs were made of semi-precious stones: for example, scarab C47238 is made of carnelian, and scarab C47243 is made of diorite, which is a material only rarely used for other scarab types. ${ }^{94}$ According to Ben-Tor, naturalistically-shaped scarabs, which have been found in funerary contexts, were dated to the Late Period and were placed on top of various body parts of the mummy, such as the neck, the chest, the belly and the hand, to protect the deceased. ${ }^{95}$ Professor of Egyptology Irmtraut Beste is convinced that all scarabs shaped with a naturalistic body must be dated to the Late Period. ${ }^{96}$ Ben-Tor and Egyptologist Regine Schulz proposed that these naturalisticallycarved scarabs served as funerary amulets. ${ }^{97}$

\section{Undecorated scarabs}

Finally, the MCH collection contains two scarabs (C47195, C47247) with plain bottoms. Undecorated scarabs were used as inlays of rings, placed in the abdominal cavity of the deceased or directly draped on mummy bandages. ${ }^{98}$ In general, scarabs of a size from 35 to $110 \mathrm{~mm}$ length (scarab C47247 has a size of $50 \times 22 \times 37 \mathrm{~mm}$ ) are considered heart scarabs, which were usually inscribed with the spell $30 \mathrm{~B}$ of the Book

\footnotetext{
88 Ben-Tor 1993, 34.

89 Ben-Tor 1993, 34.

90 Ben-Tor 1993, 34.

${ }^{91}$ C47167, C47177, C47203, C47238, C47243.

92 Ben-Tor 1997, 39; NFA 1991, no. 284.

93 Ben-Tor 1997, 39; NFA 1991, no. 284.

94 Ben-Tor 1993, 39.

95 Ben-Tor 1993, 39; NFA 1991, no. 280. 284.

96 Beste 1979, 100, no. 2138.

97 Ben-Tor 1993, 39; Schulz 2007, 170-178.

98 Regner 1995, 54 no. 58; Schulz 2007, 169 no. 131.
} 


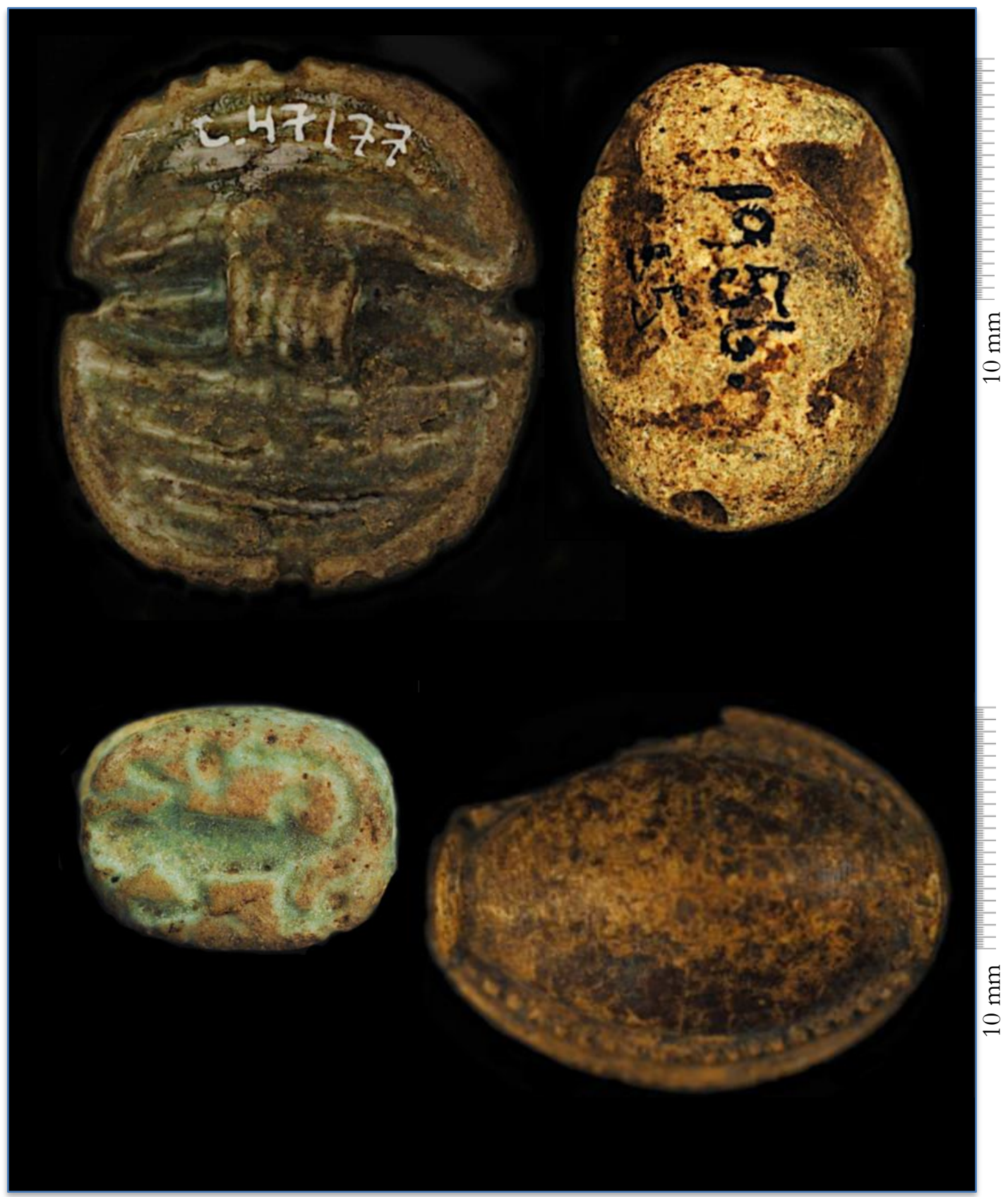

Fig. 18 (above, left) Bottom of scarab. Oslo, MCH inv. no. C47177. Fig. 19 (above, right) Back of scaraboid. Oslo, MCH inv. no. C47202. Fig. 20 (below, left) Back of scaraboid. Oslo, MCH inv. no. C47234. Fig. 21 (below, right) Back of scaraboid. Oslo, MCH inv. no. C47246. Photographs: (C) Stephanie Müller. 
of the Dead. ${ }^{99}$ However, there are undecorated scarabs also identified as heart scarabs. ${ }^{100}$ Heart scarabs were either used as inlays of pectorals hung around the neck or placed on the chest of the deceased. ${ }^{101}$ The function of the heart scarab was to magically influence the heart of the deceased at the weighing of the heart ceremony, so that the heart would not be able to be used as a witness against its owner, which was most probably also the function of scarab C47247. ${ }^{102}$

\section{Particularities of the scarabs and scaraboid seals in the MCH collection}

The collection contains five scaraboids. On the back of one (C47208) (Fig. 19) is a depiction of the Egyptian goddess Thoeris, who is the goddess of childbirth, protecting the mother and child during childbearing; Thoeris therefore played a significant role in the life of every Egyptian woman. ${ }^{103}$ The bottom of the scaraboid C47208 is inscribed with a cryptogram of the god Amun-Re. The combination of the depiction of the goddess Thoeris together with the name of Amun-Re might have served to intensify the protective power of the object as Hornung and Staehelin assumed. ${ }^{104}$ As Thoeris is a particularly important goddess for women, it can be assumed that scaraboid C47208 probably belonged to a female owner. Thoeris scaraboids do not appear in Stoof's or Keel's research on scaraboids, and the object can therefore be considered as one of the rarer finds. ${ }^{105}$

A second rather uncommon motif for a scaraboid is the lizard on the back of object C47234 (Fig. 20), which has an undecorated bottom. Lizard scaraboids are not listed in any of the studies by Hornung, Staehelin, Keel and Stoof. ${ }^{106}$ According to Hornung and Staehelin, lizards were symbols of regeneration and rebirth, as the animal is able to regenerate a lost tail. ${ }^{107}$

The three other scaraboids in the $\mathrm{MCH}$ collection are distinctly more common: scaraboid C47210 is decorated with a frog on the back, and on the bottom there is an animal-headed god holding a knife in the right hand next to a cobra. However, compared with other scarabs carrying this bottom motif, it can be assumed that 'the knife' is rather a schematically reduced wing, and the depicted figure is Seth, who became a powerful god granting protection and patronage on scarabs in the

\footnotetext{
99 Ben-Tor 1993, 17; Schlick-Nolte 1990, 167 no. 114. For a translation of the spell $30 \mathrm{~B}$ see Hornung \& Staehelin 1976, 184-187.

100 For examples see Śliwa 1985, 81 no. 128; Schulz 2007, 161-163 nos. 124. 126; Regner 1995, 69-70 no. 86. 72 no. 89. 85 no. 1042. 87 no. 1047; Schlick-Nolte 1990, 165-166 no. 113. 169-173 nos. 115-119.

101 Hornung \& Staehelin 1976, 184; Ben-Tor 1993, 17-18.

102 Hornung \& Staehelin 1976, 184

103 Stoof 1992, 97-98.

${ }^{104}$ Hornung \& Staehelin 1976, 100.

105 Stoof 1992; Keel 1995, 66-80.

106 Hornung \& Staehelin 1976, 109. Stoof and Keel did not mention any lizard scaraboids in their studies. See Keel 1995; Stoof 1992.

107 Hornung \& Staehelin 1976, 110.
} 
Nineteenth and Twentieth Dynasty. ${ }^{108}$ The frog is a symbol of the goddess of birth, Heket, and therefore Stoof assumed that frog scaraboids were symbols of life and birth in this world as well as symbols of fertility and regeneration. ${ }^{109}$ If Stoof's assumption is correct that the frog had primarily belonged to the female sphere due to the importance of the goddess Heket for women, this might possibly indicate that scaraboid C47210 belonged to a woman, who wished for protection either in this life or in the netherworld.

The other two scaraboids are one cowroid (C47246) (Fig. 21) and one scaraboid (C47201) with an undecorated, plain back belonging to Keel's type II 'Skaraboide, deren Seiten in einem rechten Winkel zur Basis stehen', which was the most common type of a scaraboid and particularly popular in Phoenicia. ${ }^{110}$

Staehelin and Stoof are convinced that scaraboids had the same function and connotations as scarabs, with the only difference that they differ in shape from scarabs, since they were made from the same material and the same motifs were engraved on the bottoms. ${ }^{111}$ Certainly a seal function can be excluded for those scaraboids with a plane base. The question remains whether scaraboids had a special connotation, as only a minority of stamp seals do not have a beetle shape.

There is an enormous variety of material that could be used in scarab and scaraboid production. It could be attested that 78 of 98 objects in the collection were made of steatite, which is therefore the most common material used. This is because it was a very soft stone, easy to carve, and because it hardened after burning. ${ }^{12}$ Three scarabs (C47177, C47185, C47239) are made of faience. Among the rarely used materials in the collection is one scarab (C42508) made of bone or ivory, two scarabs made of clay (C47213, C47218), one carnelian scarab (C47238), two green jasper scarabs (C47203, C47207), one glass fragment (C47416), one scarab made of basalt (C47247), one made of diorite (C47243), one pottery scarab (C41094) and the modern forgery $\mathrm{C} 47249$, which is made of sandstone. Two scarabs are made of a compound material (C47174, C47179) and three (C47195, C47215, C47216) are made of dark stone.

Furthermore, colours had an important meaning and special connotations in the ancient Egyptian culture. Several of the scarabs were glazed with a greenish blue colour. The colour green symbolised regeneration, life and growth, similar to the colour blue, which was associated with the Nile and therefore represented fertility, life and rebirth. ${ }^{113}$ Several of the scarabs were painted with a black colour, which was associated with the underworld, resurrection and symbolised fertility. ${ }^{114}$ The stated

108 See Ben-Tor 1993, 38; Keel 1990a, 235 fig. 54; Keel 1990b, 305 fig. 69; Schlick-Nolte 1990, 98; Hölbl 1986, 217. pl. 141, 3c.

109 Stoof 1992, 243.

110 Keel 1995, 63-64; Keel-Leu 1991, 84-86 nos. 101-103.

111 Staehelin 1982, 18; Stoof 1992, 143-148.

112 Keel 1995, 147-148.

113 Wilkinson 1994, 107-109.

114 Wilkinson 1994, 109-110. 


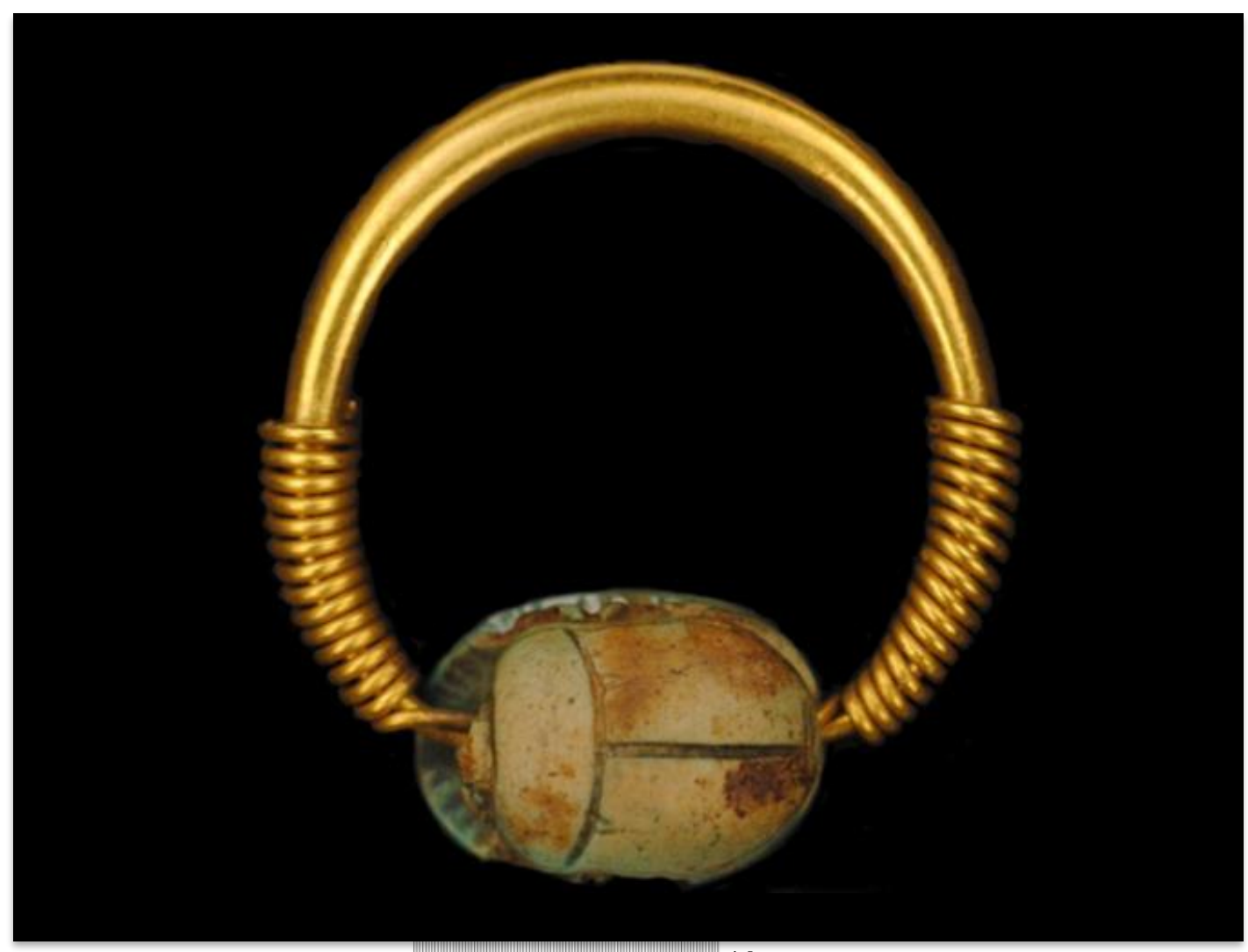

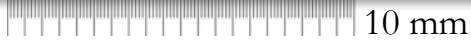

Fig. 22 Back of scarab. Oslo, MCH inv. no. C47248.

Photograph: (C) Stephanie Müller.

connotations of the colours correspond to the meaning of the bottom motifs on scarabs, as most of them symbolised regeneration and were associated with the netherworld.

The size of the objects in the $\mathrm{MCH}$ collection varies, although the majority range between 10 and $20 \mathrm{~mm}$. The smallest object, scarab C47224, has a length of only $9 \mathrm{~mm}$, while the largest object, scarab C47249, has a length of $88 \mathrm{~mm}$. Archaeologist Olga Tufnell attested that scarabs with the same motif often had the same size. ${ }^{115}$ This statement by Tufnell applies to several scarabs in the collection of the MCH: the scarabs C47196, C47197, and C47198 are inscribed with the same $M n$ $h p r$ - ra sequence on their bottom and the size of the objects is $19-20 \mathrm{~mm}$. Furthermore, the scarabs C41228 and C41249 are similar in motif and size, both being $13 \mathrm{~mm}$ long. Additionally, the size of the scarabs C47183, C47186, C47188, C47189, C47190, which are attested by their motifs as typical for the period of Ramesside massproduction, are similar in size, ranging between 18 and $20 \mathrm{~mm}$.

115 Tufnell 1984, 28. 


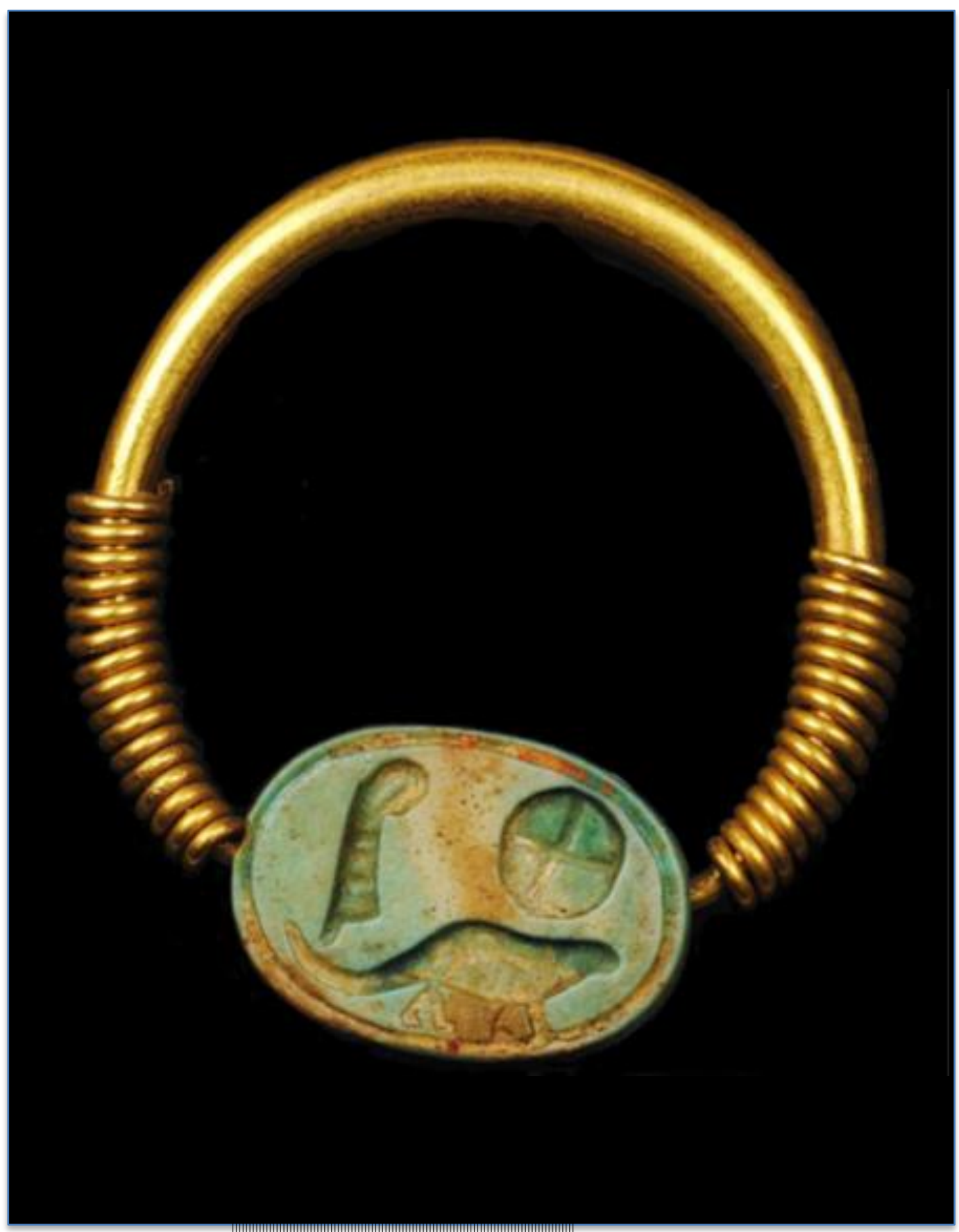

|

Fig. 23a Bottom of scarab. Oslo, MCH inv. no. C47248.

Photograph: (C) Stephanie Müller 


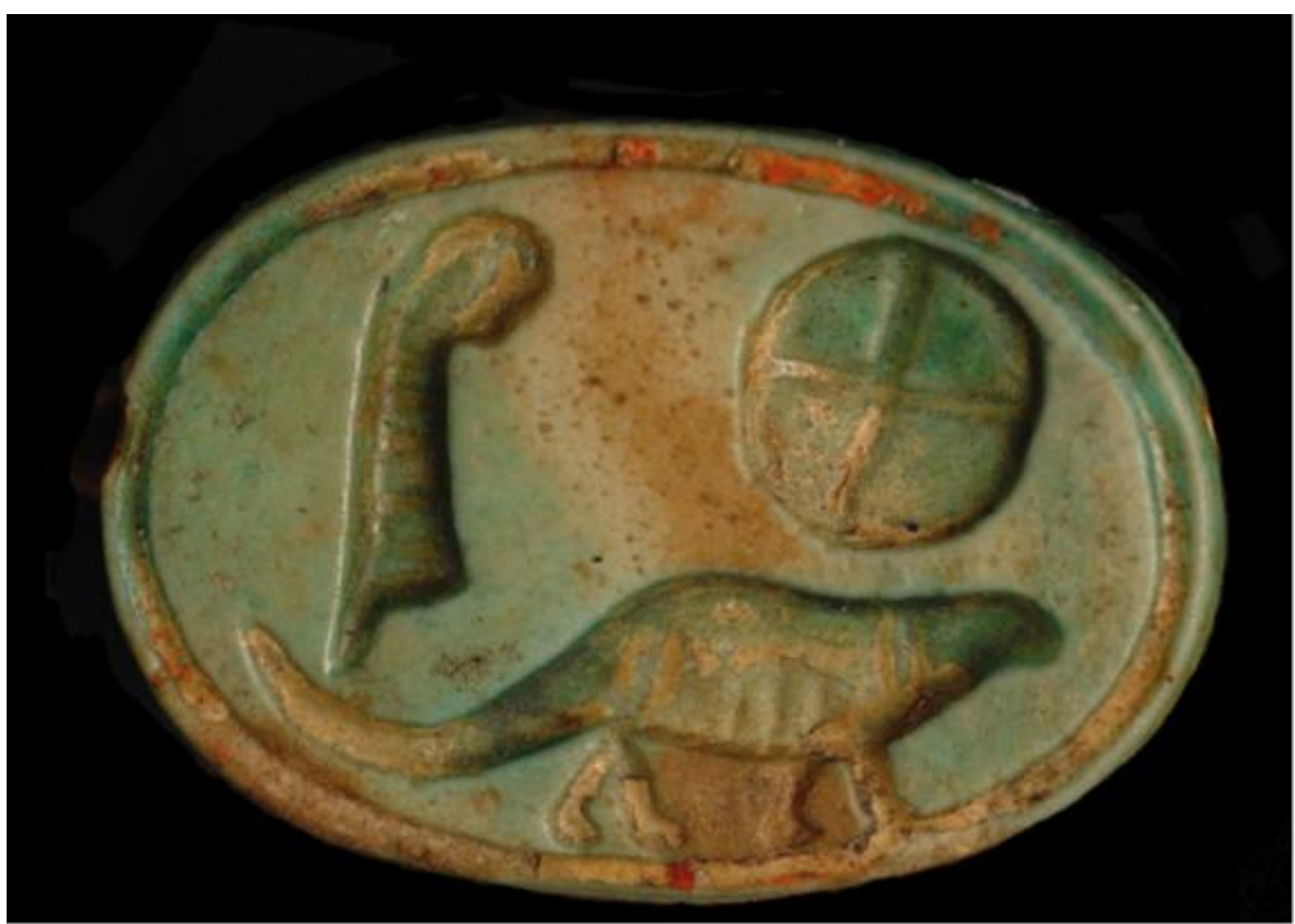

Fig. $23 b$ Bottom of scarab, close-up. Oslo, MCH inv. no. C47248.

Photograph: (C) Stephanie Müller.

The majority of scarabs were either attached to rings or worn on strings around the neck or wrists, which explains the lengthways piercing of the scarabs. The only scarabs usually not pierced were heart- and commemorative scarabs and in the Late Period scarabs with a naturalistically shaped body. One scarab of the Late Period, scarab C47177, possesses a loop through which the object was probably applied to mummy bandages. Scarab C47243 is an exception, as it is pierced laterally. This characteristic cannot be explained. Three scarabs are not pierced, among them the forgery scarab C47249, which was certainly not pierced due to its size (length $88 \mathrm{~mm}$ ). However, there are eleven scarabs that are not completely pierced. ${ }^{116}$ According to Staehelin, if scarabs, despite the exceptions mentioned, are not pierced completely this is an indication to doubt the authenticity of the objects. ${ }^{117}$ Aside from the suggested forgeries mentioned above, the other objects in the collection are considered authentic.

An object of particular interest in the MCH collection is the scarab C47248 (Figs. 22-23), which is attached to a pure golden ring, which identifies the object as very

116 C41229, C41249, C47170, C47171, C47172, C47173, C47174, C47182, C47208, C47210, C47244.

117 Staehelin 1982, 61. 
precious and explains how the scarab was worn. This scarab is the most significant object in the collection, not due only to its precious material, but also to its filigree workmanship. The bottom of scarab C47248 is engraved with a horizontally orientated sign sequence displaying an ichneumon, a njwt-sign (O49) and a $S_{w}$-feather (H6). ${ }^{118}$ The motif of an ichneumon, a $S_{w}$-feather (H6) and a sun-disc sign (N5) is frequently documented as a cryptogram for the god's name Amun. However, on scarab C47248 there is no sun-disc sign (N5) inscribed, but rather a njwt-sign (O49). This combination of signs is without any parallel on scarabs. The variation of a very common sign sequence might be explained by the aim of the owner to express his individuality by intentionally using the cryptographic writing of the name Amun. The replacement of the sun-disc sign with a sign that is similar in form and shape could be an approach to make this object singular and more personal, while the trigram of Amun can still be recognised. It is possible to assume that this scarab on a golden ring was used as a personal seal, inscribed with a family emblem or an expression of personal piety in dedication to the god Amun. The function of this ring was probably to seal and authenticate documents with an individual design.

\section{Conclusion}

The variety of material, quality, motif arrangements and size in the scarab collection of the MCH displays the extraordinary diversity of scarab production. Although often similar in motif, each scarab is a unique object providing insights into the religious beliefs and hopes of the common people of ancient Egypt. As the majority of the scarabs and scaraboid seals in the collection have bottom motifs connected to a funerary context, displaying symbols of regeneration, overcoming death and divine protection, they confirm their importance as protective amulets for daily life and the afterlife, and attest to the wide range of religious beliefs and conceptions in ancient Egyptian culture. However, scarabs had multi-layered functions, as they were also used as private-name seals in administrative contexts, or possibly used by the king for propaganda purposes. Scarab C47182 is a good example of the multifunctional usage of scarabs, as the object is engraved with the name Mnjj, which is attested as a person's name for the Middle and New Kingdom, and therefore indicates the use of the object as a private-name seal. However, the name could equally refer to the first king of the First Dynasty, Menes, which might express the protective function of the object. The assignment of motifs to either the temporal sphere or the netherworld cannot strictly be undertaken, as scarabs were in general frequently described without known find contexts and the inherent protective powers were needed for both spheres. However, the naturalistically-shaped scarabs certainly had a funerary connotation, as they were appliqued or wrapped in mummy bandages of the deceased. The same restricted funerary context is documented for all heart scarabs, which were placed on the body of the deceased, as is likely to be the case for scarab C47247.

118 See 'List of Hieroglyphic Signs' in Gardiner 1957, 438-548. 
The origin of the scarabs and scaraboid seals in the collection of the $\mathrm{MCH}$ is unknown, and as the production of scarabs was widespread during ancient Egyptian times, it cannot be said with certainty whether objects were produced in Egypt or abroad. However, as a large number of scarabs have been found in Palestine ${ }^{119}$ and the bottoms of scarab C47202 and scarab C47183 are depicted with the Canaanite gods $\mathrm{Ba}^{\mathrm{c}}$ al-Seth and Reshef, cultural exchange and contact with the neighbouring countries has to be assumed.

Although scarabs have frequently been discussed and studied, there are still many unanswered questions awaiting further investigation. For example, the allocation of particular motifs to certain classes of society has not yet been studied.

Possibly, a gender division of motifs might also be discerned on scarabs. For instance, the depiction of Thoeris on scaraboid C47208 or the child formula on scarab C47187 might indicate a female owner, as both motifs distinctly belong to the female sphere. On the other hand, hunting motifs could perhaps be allocated to the male sphere. Aside from the possible gender division of motifs, scarabs may also have indicated the social class of the owner, as the motifs may provide hints about the rank of the owner in society. For example, due to their low quality, the scarabs of the Ramesside mass-production indicate widespread use, most probably by people of lower social status, while the fine inner carving of the motif on the bottom of scarab C47 248 may indicate an owner of a higher social status. This assumption is supported by the fact that scarab C47248 is attached to a golden ring, which certainly could not be afforded by many ancient Egyptians regardless of their social status.

Stephanie Müller, Magistra Artium

The Goethe-Institute, Munich

Former affiliation: Institute of Egyptology

University of Heidelberg

E-mail: st.mueller09@googlemail.com

119 Keel 1995; 1997. 


\section{Bibliography}

Ben-Tor, D. 1993: The Scarab. A Reflection of Ancient Egypt. Jerusalem: Israel Museum.

Ben-Tor, D. 1997: 'The Relations between Egypt and Palestine in the Middle Kingdom as reflected by contemporary Canaanite Scarabs', Israel Exploration Journal 47: 162-189.

Beste, I. 1979: Skarabäen 2, Corpus Antiquitatum Aegyptiacarum Kestner-Museum Hannover. Mainz am Rhein: Philip von Zabern.

Cooney, K. \& Tyrrell, J. 2005: 'Scarabs in the Los Angeles County Museum of Art. Part I. Distributed propaganda or intimate protection?' PalArch's Journal of Archaeology of Egypt/Egyptology 4, 1: 1-14.

Cornelius, I. 1994: The Iconography of the Canaanite Gods Reshef and Ba al. Late Bronze and Iron Age I Periods (c 1500-1000 BCE) (OBO 140). Fribourg: University Press Fribourg: Fribourg.

de Wit, C. 1980: Le Rôle et le Sens du Lion dans l'Égypte Ancienne. Deuxième edition avec nouveaux addenda et corrigenda. Luxor: Hussein.

Drioton, E. 1933: 'Essai sur la cryptographie privée de la fin de la XVIIIe Dynastie', Revue D'Égyptologie 1: 1-50.

Drioton, E. 1940: 'Receuil de Cryptographie Monumentale', Annales du Service des Antiquités de l'Égpyte 40: 305-427.

Drioton, E. 1955: ‘Scarabée de la collection Gurewich’, BSFE 19: 59-66.

Drioton, E. 1956: 'Vœux inscrits sur des scarabées’, MDAIK 14: 34-41.

Drioton, E. 1957: 'Trigrammes d'Amon', in H.W. Duda (ed), Wiener Zeitschrift für die Kunde des Morgenlandes 54 (Festschrift Hermann Junker), 11-33. Vienna: Selbstverlag des Orientalischen Institutes.

Erman, E. \& Grapow, H. (eds) 1955: Wörterbuch der Ägyptischen Sprache. Im Auftrage der Deutschen Sprache, vol. 2. Berlin: Akademie.

Gardiner, Sir A. 1957: Egyptian Grammar. Being an Introduction to the Study of Hieroglyphs, $3^{\text {rd }}$ ed. Oxford: Griffith Institute and Ashmolean Museum. 
Grenfell, A. 1916: 'The Grenfell Collection of Scarabs', in F. Petrie (ed.), Ancient Egypt 1916, 22-31. London: British School of Archaeology in Egypt.

Hall, H. R. 1929: Scarabs. London: British Museum.

Helck, W. 1984: 'Spirale', in W. Helck \& W. Westendorff (eds), LÄ V, 1157-1160. Wiesbaden: Harrassowitz Verlag.

Hoch, J. E. 1994: Semitic Words in Egyptian Texts of the New Kingdom and Third Intermediate Period. Princeton: Princeton University Press.

Hornung, E. \& Staehelin, E. (eds) 1976: Skarabäen und andere Siegelamulette aus Basler Sammlungen (Ägyptische Denkmäler in der Schweiz 1). Mainz am Rhein: Philipp von Zabern.

Houlihan, P. F. \& Goodman, S. M. 1986: The Birds of Ancient Egypt, The Natural History of Egypt 1. Warminster: Aris \& Phillips and Atlantic Highlands NJ.

Hölbl, G. 1986: Ägyptisches Kulturgut im phönikischen und punischen Sardinien (Études préliminaires aux religions orientales dans l'Empire romain 102), 2 vols. Leiden \& Boston: Brill Academic Publishing.

Jaeger, B. 1982: Essai de Classification et Datation des Scarabées Menkhéperrêe (Orbis biblicus et orientalis, Series archaeologica 2). Fribourg: Suisse Éd. Univ.

Kantor, H. 1947: The Aegean and the Orient in the Second Millennium B.C. (Monographs on Archaeology and Fine Arts 4). Bloomington: Principia Press.

Keel, O. 1990a: La glyptique du Tell Keisan (1971-1976). Avec une contribution de É. Puech, in O. Keel, M. Shuval \& C. Uehlinger (eds), Studien zu den Stempelsiegeln aus Palästina/Israel, vol. III (OBO 100), 163-260. Freiburg and Göttingen:

Universitätsverlag.

Keel, O. 1990b: Berichtigungen und Nachträge zu den Beiträgen II-IV in O. Keel, M. Shuval \& C. Uehlinger (eds), Studien zu den Stempelsiegeln aus Palästina/Israel, vol. III (OBO 100), 98-321. Freiburg and Göttingen: Universitätsverlag.

Keel, O. 1995: Corpus der Stempelsiegel-Amulette aus Palästina/Israel. Von den Anfängen bis zur Perserzeit. Einleitung (OBO 10). Freiburg and Göttingen: Universitätsverlag.

Keel, O. 1997: Corpus der Stempelsiegel-Amulette aus Palästina/Israel. Von den Anfängen bis zur Perserzeit. Katalog Band I: Von Tell Abu Farag bis 'Atlit (OBO 13). Freiburg and Göttingen: Universitätsverlag. 
Keel-Leu, H. 1989: 'Die Frühesten Stempelsiegel Palästinas. Von den Anfängen bis zum Ende des 3. Jahrtausends', in O. Keel, H. Keel-Leu \& S. Schroer (eds), Studien zu den Stempelsiegeln aus Palästina/Israel II, 1-38. Freiburg and Göttingen: Universitätsverlag.

Keel-Leu, H. 1991: Vorderasiatische Stempelsiegel. Die Sammlung des Biblischen Instituts der Universität Freiburg/Schweiz, (OBO 110). Freiburg and Göttingen: Universitätsverlag.

Köhler, U. 1980: 'Löwe, Löwen-Köpfe, Löwen-Statuen', in W. Helck \& W. Westendorff (eds), LÄ III, 1080-1090. Wiesbaden: Harrassowitz Verlag

Martin, G. 1971: Egyptian Administrative and Private-Name Seals. Principally of the Middle Kingdom and Second Intermediate Period. Oxford: Griffith Institute.

Martin, K. 1990: 'Einige Bemerkungen zur Gefiederten Kartusche' in A. Eggebrecht \& B. Schmitz (eds), Festschrift für Jürgen von Beckerath zum 70. Geburtstag am 19. Februar 1990 (Hildesheimer Ägyptologie Beiträge 30), 175-184. Hildesheim: Gerstenberg.

Murray, M. A. 1949: ‘Some Canaanite Scarabs’, Palestine Exploration Quarterly 81: 9299.

NFA Classical 1991: Auctions, Scarabs and Design Amulets. A glimpse of ancient Egypt in miniature, auction 11.12.1991, New York: NFA Classical Auctions Inc.

Niccacci, A. 1980: Hyksos Scarabs (Studium Biblicum Franciscanum Museum 2). Jerusalem: Studium Biblicum Franciscanum Museum.

Osing, J. 1980: 'Lautsystem', in W. Helck \& W. Westendorff (eds), LÄ III, 945-949. Wiesbaden: Harrassowitz Verlag.

Özgüç, T. 1993: 'Alabaster Idols and Statuettes from Kültepe', in M. Frangipane, H. Hauptmann, M. Liverani, P. Matthiae \& M. Mellink (eds), Between the Rivers and over the Mountains (Archaeologica Anatolica et Mesopotamica, Alba Palmieri dedicata, Dipartimento di Scienze Storiche, Archeologiche e Antropologiche dell'Antichità), 509-515. Rome: Università La Sapienza.

Petrie, W. M. F. 1919: 'Notes and Queries', Palestine Exploration Fund Quarterly Statement 51: 46.

Petrie, W. M. F. 1925: Button and Design Scarabs (Publications of the Egyptian Research Account and the British School of Archaeology in Egypt 38). London: Quaritch. 
Petrie, W. M. F. 1930: Beth-Pelet I (Tell Fara) (Publications of the Egyptian Research Account and the British School of Archaeology in Egypt 48). London: Quaritch.

Ranke, H. 1935: Die Ägyptischen Personennamen 1. Glückstadt: J. J. Augustin.

Regner, C. 1995: Skarabäen und Skaraboide (Bonner Sammlung von Aegyptiaca 1). Wiesbaden: Harrassowitz.

Reisner, G. A. \& Wheeler, N. F. 1930: 'The Art of Seal Carving in the Middle Kingdom', Bulletin of the Museum of Fine Arts 28, no. 167: 47-55.

Richards, F. 2001: The Anra Scarab. An archaeological and historical approach (BAR International Series 919). Oxford: BAR Publishing.

Schenkel, W. 1986: 'Syllabische Schreibung', in W. Helck \& W. Westendorff (eds), LÄ VI, 114-122. Wiesbaden: Harrassowitz Verlag.

Schlick-Nolte, B. \& Droste zu Hülshoff, V. 1990: Skarabäen, Amulette und Schmuck. Liebighaus-Museum Alter Plastik (Ägyptische Bildwerke 1). Melsungen: Gutenberg Verlag.

Schulman, A.R. 1970: 'The Ossimo Scarab', Bollettino del Centro Camuno di Studi Preistorici 5: 193-196.

Schulz, R. 2007: Kheperu-Scarabs. Scarabs, Scaraboids, and Plaques from Egypt and the Ancient Near East in the Walters Art Museum Baltimore. Baltimore: Halgo Inc.

Śliwa, J. 1985: Egyptian Scarabs, Scaraboids and Plaques from the Cracow Collection (Studia z archeologii śródziemnomorskiej 8). Warsaw: University of Warsaw Press.

Staehelin, E. 1982: Ägyptens Heilige Pillendreher. Von Skarabäen und anderen Siegelamuletten. Basel: GS Verlag.

Starkey, J. L. \& Harding, L. 1932: Beth-Pelet II. Beth-Pelet Cemetery (Publications of the Egyptian Research Account and the British School of Archaeology in Egypt 52). London: British School of Archaeology in Egypt.

Stock, H. 1942: Studien zur Geschichte und Archäologie der 13. bis 17. Dynastie Ägyptens unter besonderer Berücksichtigung der Skarabäen dieser Zwischenzeit (Ägyptologische Forschungen 12). Glückstadt: Augustin.

Stoof, M. 1983: ‘Die Stempelsiegel mit Spiralmuster im Alten Ägypten’, Hallische Beiträge zur Orientwissenschaft 5: 29-55. 
Stoof, M. 1992: Ägyptische Siegelamulette in menschlicher und tierischer Gestalt. Eine archäologische und motivgeschichtliche Studie (Europäische Hochschulschriften 38, Archäologie 41). Frankfurt am Main: Peter Lang.

Tufnell, O. 1953: Lachish III (Tell ed-Duweir). The Iron Age, vol. II. London: Geoffrey Cumberlege and Oxford University Press.

Tufnell, O. 1984: Studies on Scarab Seals. Scarab Seals and their Contribution to History in the Early Second Millennium B.C., 2 vols. Warminster: Aris \& Phillips Ltd.

Ward, W. A. 1971: Egypt and the East Mediterranean World 2200-1900 B.C. Studies in Egyptian Foreign Relations during the First Intermediate Period. Beirut: American University of Beirut.

Ward, W. A. 1978: Studies on Scarab Seals I. Pre-12th Dynasty Scarab Amulets.

Warminster: Aris \& Phillips Ltd.

Ward, W. A. \& Dever, W. G. 1994: Studies on Scarab Seals III. Scarab Typology and Archaeological Context. San Antonio: Van Siclen.

Weill, R. 1917: 'La Fin du Moyen Empire Égyptien. Compléments', JA 11/9: 5-143.

Weill, R. 1918: La Fin du Moyen Empire Égyptien, 2 vols. Paris: A. Picard.

Weill, R. 1953: XIIe dynastie, Royauté de Haute-Égypt et domination Hykesos dans le Nord (Bibliothèque d'étude, Institut Français d'Archéologie Orientale du Caire 26. Cairo: Institut français d'archéologie orientale, Le Caire.

Wilkinson, R. H. 2008: Egyptian Scarabs. Bloomsbury: Shire Publications. 